\title{
4. O PODER JUDICIÁRIO E AS LEIS ORÇAMENTÁRIAS
}

\subsection{O orçamento público}

Atribui-se à Magna Carta inglesa, de 1217, a origem dos orçamentos públicos. O art. 12 previa que "nenhum tributo ou auxílio será instituído no Reino, senão pelo seu conselho comum, exceto com o fim de resgatar a pessoa do Rei, fazer seu primogênito cavaleiro e casar sua filha mais velha uma vez, e os auxílios para esse fim serão razoáveis em seu montante". ${ }^{93}$

Nasce a convicção de que os Estados precisam organizar suas finanças, estabelecendo a necessidade de leis para instituir tributos e autorizar as despesas do Governo. Com o decorrer do tempo e a evolução na organização dos Estados, esta convicção consolidou-se. Jesse Burkhead considera o ano de 1822 o marco do início do orçamento, da forma como o conhecemos hoje, pois foi naquele ano que o Chanceler do Erário britânico passou a apresentar ao Parlamento a exposição sobre a situação das finanças públicas, tendo em vista a necessidade de justificar as receitas e as despesas que compunham o fundo geral criado em 1787 (pelo Consolidated Fund Act) para gerenciar as atividades financeiras do Governo. ${ }^{94}$

Inicialmente, esses incipientes orçamentos públicos eram documentos que tinham o caráter de peças contábeis, em que se faziam as previsões de receitas e autorizações de despesas para um determinado período - o exercício financeiro. Essa é, em síntese, o que se denomina concepção clássica do orçamento.

As necessidades da Administração Pública, aliadas ao desenvolvimento das técnicas orçamentárias, foram aos poucos modificando a concepção clássica do orçamento público, fazendo com que assumisse uma função importante na condução das

\footnotetext{
${ }^{93}$ Apud BURKHEAD, Orçamento público, p. 4.

${ }^{94}$ Idem, p. 5.
} 
políticas públicas. Vários fatores influíram nessa tendência, destacando-se o intenso intervencionismo estatal nas atividades econômicas.

$\mathrm{O}$ orçamento torna-se um instrumento fundamental no planejamento e na programação da atividade econômica do Governo, adquirindo, como bem ressalta Giuliani Fonrouge, uma condição dinâmica, e tornando-se "un instrumento mediante el cual el Estado actúa sobre la economía". ${ }^{95}$

As técnicas e os conceitos orçamentários modernos refletem essa nova função dos orçamentos públicos, surgindo os conceitos de orçamento-programa, orçamento de desempenho (performance budget) e PPbS (planning, programming and budgeting system), que, embora não tenham distinção nítida entre si, demonstram que o orçamento, inequivocamente, abandona sua concepção clássica para assumir a condição de instrumento da ação governamental.

A técnica de orçamento por programas, ou orçamento-programa, hoje largamente adotada, consiste em um tipo de orçamento vinculado ao planejamento das atividades governamentais, consubstanciando-se em um documento "em que se designam os recursos de trabalho e financeiros destinados à execução dos programas, subprogramas e projetos de execução da ação governamental, classificados por categorias econômicas, por função e por unidades orçamentárias". ${ }^{96}$

Por meio dessa técnica, que tem como ponto central adotar a classificação das despesas públicas pelo critério funcional-programático ${ }^{97}$, os recursos públicos passam a ter sua previsão orçamentária destinada ao cumprimento dos diversos programas de governo, o que vincula os valores à realização dos referidos programas e das respectivas metas.

É difícil identificar a origem dessa técnica com precisão, uma vez que resultou de aperfeiçoamentos de técnicas orçamentárias ao longo do tempo; no entanto, alguns fatos, por serem relevantes em seu processo de desenvolvimento, devem ser destacados. O governo americano deu grandes contribuições no período do pós-guerra com os

\footnotetext{
${ }^{95}$ Derecho financiero, v. I, p. 145.

${ }^{96}$ SILVA, José Afonso da. Orçamento-programa no Brasil, p. 41.

${ }^{97}$ Que será vista com mais detalhes no item 4.3.3.
} 
trabalhos realizados pela Comissão Hoover (Commission on Organization of Executive Branch of the Government) e pelo Bureau de Orçamento (Office of Management and Budget), tendo essa Comissão expedido relatório no qual constava como primeira recomendação a adoção de orçamento baseado em funções, atividades e projetos. Em 1955, houve uma segunda Comissão Hoover, que examinou os avanços alcançados com as modificações nas técnicas orçamentárias e manteve a orientação no sentido de sua adoção por todas as esferas de governo do país. ${ }^{98}$ Em manual publicado em 1955, a técnica de orçamento-programa foi sistematizada pela ONU. ${ }^{99}$

\subsection{O orçamento público no Brasil e o Poder Judiciário}

As normas a respeito de contas públicas no Brasil remontam a 1808, com a criação do Tesouro Nacional. As primeiras Constituições, de 1824 e de 1891, pouco cuidaram de matéria orçamentária, que era regulada inicialmente por leis ordinárias, havendo referência apenas à competência do Poder Legislativo para "fixar anualmente as despesas públicas e repartir a contribuição direta" (Constituição de 1824, art. 15, X) e "orçar a receita, fixar a despesa federal anualmente e tomar as contas da receita e despesa de cada exercício financeiro" (Constituição de 1891, art. 34, 1º). Em 1831, foi aprovada a primeira lei orçamentária. ${ }^{100}$ A Constituição de 1934 tratou especificamente do tema, dedicando a Seção IV do Capítulo II à elaboração do orçamento, na qual atribui ao Presidente da República o dever de enviar à Câmara dos Deputados a proposta de orçamento, bem como consagra os princípios orçamentários da unidade e da exclusividade (art. 50). A Constituição de 1937, em seu art. 67, previa a criação de um departamento administrativo junto à Presidência da República destinado a aperfeiçoar a Administração Pública e a organizar a proposta orçamentária, além de conter várias outras normas de natureza orçamentária nos arts. 68 a 72.

O DASP - Departamento Administrativo do Serviço Público - foi criado pelo Decreto-Lei $\mathrm{n}^{\mathrm{o}} 579$, de $30.7 .1938^{101}$, sendo o órgão que promoveu o desenvolvimento da técnica orçamentária no Brasil, dando início à modernização da Administração

\footnotetext{
${ }^{98}$ BURKHEAD, Orçamento público, p. 177-9.

99 GIACOMONI, Orçamento público, p. 152.

${ }^{100}$ PETREI, Budget and control, p. 233.

${ }^{101}$ Sucedendo o Conselho Federal do Serviço Público Civil, criado pela Lei no 284, de 28.10.1936.
} 
Pública Federal e transformando o orçamento em instrumento que permitisse o planejamento das atividades governamentais futuras. ${ }^{102}$

Começaram a aparecer os primeiros planos de investimento a longo prazo. $\mathrm{O}$ Decreto-Lei $\mathrm{n}^{\circ}$ 1.058, de 19.1.1939, instituiu o Plano Especial de Obras Públicas e Aparelhamento da Defesa Nacional, e o Decreto $n^{\circ}$ 6.144, de 29.12.1943, instituiu o Plano de Obras e Equipamentos. ${ }^{103}$ A Constituição de 1946 inovou em matéria orçamentária ao criar os planos setoriais e regionais, que preveem vinculações com a receita, gerando reflexos no orçamento. ${ }^{104}$ Surgiram depois o Plano SALTE (Saúde, Alimentação, Transporte e Energia - Lei $\mathrm{n}^{0}$ 1.102, de 18.5.1950), o Programa de Metas $(1956)^{105}$ e outros que se seguiram ${ }^{106}$, até que se iniciassem os planos plurianuais, como determinado pela Constituição de 1988.

Em 17.3.1964, foi editada a Lei $n^{\circ} 4.320$, que "estatui normas gerais de direito financeiro para elaboração e controle dos orçamentos e balanços da união, dos Estados, dos Municípios e do Distrito Federal”, diploma legal ainda vigente para regular esse assunto.

Em 11.5.1964, por meio do Decreto ${ }^{0}$ 53.914, foi criado o cargo de Ministro do Planejamento (Ministro Extraordinário do Planejamento e Coordenação Econômica), com a função de dirigir e coordenar a revisão do plano nacional de desenvolvimento econômico; coordenar e harmonizar, em planos gerais, regionais e setoriais, os programas e projetos elaborados por órgãos públicos; coordenar a elaboração e a execução do Orçamento Geral da união e dos orçamentos dos órgãos e entidades subvencionadas pela união, harmonizando-os com o plano nacional de desenvolvimento econômico. ${ }^{107}$

A técnica de orçamento-programa foi expressamente acolhida pela legislação brasileira no art. $1^{\circ}$ da Lei $n^{\circ} 4.320 / 64$, ao estabelecer que a "Lei de Orçamento conterá

\footnotetext{
102 BRASIL, Ministério do Planejamento, Orçamento e Gestão, Sistema orçamentário: histórico das atividades orçamentárias, p. 1.

103 SILVA, José Afonso da. Orçamento-programa..., p. 24-7.

${ }^{104}$ BRASIL, Ministério do Planejamento, Orçamento e Gestão. Sistema orçamentário, p. 3.

${ }^{105}$ SILVA, José Afonso da. Orçamento-programa..., p. 28.

${ }^{106}$ Veja em GIACOMONI (Orçamento público, p. 222-3) descrição dos planos de investimento brasileiros.

${ }^{107}$ BRASIL, Ministério do Planejamento, Orçamento e Gestão, Sistema orçamentário, p. 4.
} 
a discriminação da receita e despesa de forma a evidenciar a política econômicofinanceira e o programa de trabalho do Governo, obedecidos os princípios da unidade, universalidade e anualidade", e também no Decreto-Lei $\mathrm{n}^{\circ}$ 200, de 25.2.1967108, ao prever, em seu art. 16, que "em cada ano, será elaborado um orçamento-programa, que pormenorizará a etapa do programa plurianual a ser realizada no exercício seguinte e que servirá de roteiro à execução coordenada do programa anual".

Atualmente, o Brasil adota três leis orçamentárias na organização de suas finanças públicas - plano plurianual, lei de diretrizes orçamentárias e a lei orçamentária -, as quais se vinculam de modo a estabelecer uma política de programação da atividade financeira do Estado, sendo utilizados critérios de classificação orçamentária que procuram vincular as despesas aos resultados, em atenção às diretrizes fixadas pela técnica do orçamento-programa. ${ }^{109}$

A adoção deste sistema foi objeto de intensas discussões por ocasião da elaboração da Constituição de 1988. A Assembleia Nacional Constituinte, instalada em março de 1987, organizou seus trabalhos em três etapas: as Comissões Temáticas, a Comissão de Sistematização e o Plenário. A principal Comissão Temática que tratou dos orçamentos públicos foi a Comissão do Sistema Tributário, Orçamento e Finanças, em especial na sua subcomissão sobre Orçamento e Fiscalização Financeira. Durante as discussões nessa comissão, houve divergências quanto à participação do Poder Legislativo na elaboração da lei orçamentária, tendo surgido inicialmente a ideia de um orçamento bianual. A ideia não foi acolhida, substituindo-a pela elaboração de uma lei com características de pré-orçamento. A evolução dessa ideia resultou na aprovação do sistema hoje vigente, com as três leis de natureza orçamentária. ${ }^{110}$

Far-se-á uma breve explicação sobre esse mecanismo de organização das finanças para que, em seguida, situemos o Poder Judiciário neste contexto.

\footnotetext{
${ }^{108}$ Dispõe sobre a organização da Administração Federal.

${ }^{109}$ Segundo Ricardo Lobo Torres, a "tripartição do planejamento orçamentário, adotada pela Constituição brasileira, denota a influência recebida da Constituição da Alemanha, que prevê o plano plurianual (eine mehrjährige Finanzplanung - art. 109, 3), o plano orçamentário (Haushaltsplan art. 110); e a lei orçamentária (Haushaltsgesetz - art. 110)" (Tratado..., p. 60).

${ }^{110}$ AFONSO, José Roberto R. Memória da Assembleia Constitutinte de 1987/88: as finanças públicas.
} 
O plano plurianual é lei de iniciativa do chefe do Poder Executivo, cuja finalidade é estabelecer, de forma regionalizada, as diretrizes, os objetivos e as metas da Administração Pública Federal para as despesas de capital e outras delas decorrentes, bem como para as relativas aos programas de duração continuada $\left(\mathrm{CF}\right.$, art. $165, \mathrm{I}$ e $\left.\S 1^{\circ}\right)$.

A lei de diretrizes orçamentárias, prevista na legislação brasileira ${ }^{111}$, também é lei de iniciativa do chefe do Poder Executivo, tendo a finalidade de prever as metas e as prioridades da Administração Pública, incluindo as despesas de capital para o exercício financeiro subsequente, orientar a elaboração da lei orçamentária anual e dispor sobre as alterações na legislação tributária, bem como estabelecer a política de aplicação das agências financeiras oficiais de fomento (CF, art. 165, II e $\left.\S 2^{\circ}\right)$.

A lei orçamentária anual, como as duas anteriores, é de iniciativa do chefe do Poder Executivo e tem a finalidade de discriminar a receita e despesa de forma a evidenciar a política econômico-financeira e o programa de trabalho do Governo (Lei $\mathrm{n}^{\circ}$ 4.320/64, art. $2^{\circ}$ ).

$\mathrm{Na}$ esfera federal, a lei orçamentária anual compreende três orçamentos:

a) orçamento fiscal, referente aos poderes da união, seus fundos, órgãos e entidades da Administração direta e indireta, inclusive fundações instituídas e mantidas pelo Poder Público;

b) orçamento de investimento das empresas em que a união, direta ou indiretamente, detenha a maioria do capital social com direito a voto;

c) orçamento da seguridade social, abrangendo todas as entidades e órgãos a ela vinculados, da administração direta ou indireta, bem como os fundos e fundações instituídos e mantidos pelo Poder Público.

Compõem a lei orçamentária: ${ }^{112}$

a) o sumário geral da receita, por fontes, e da despesa, por funções de Governo;

\footnotetext{
111 Por inspiração das Constituições alemã e francesa, como nos informa Ricardo Lobo Torres (Tratado de direito constitucional financeiro e tributário, p. 66).

${ }^{112}$ Lei $^{\circ} 4.320 / 64$, art. $2^{\circ}, \S 1^{\circ}$; LC 101/00 (LRF), art. 5º I e II.
} 
b) quadro demonstrativo da receita e da despesa segundo as categorias econômicas;

c) quadro discriminativo da receita, por fontes, e respectiva legislação;

d) quadro das dotações por órgãos do Governo e da Administração;

e) Anexo de Metas Fiscais;

f) demonstrativo da compatibilidade da programação dos orçamentos com os objetivos e as metas constantes do Anexo de Metas Fiscais;

g) demonstrativo regionalizado do efeito, sobre as receitas e despesas, decorrentes da concessão de benefícios fiscais.

É importante ressaltar que, entre os vários princípios orçamentários, está o da unidade orçamentária, segundo o qual o orçamento deve ser uno, ou seja, todas as receitas e despesas devem constar de um único documento. Esse conceito, porém, foi adaptado e modernizado, para hoje entender-se que a concepção de unidade orçamentária admite que o orçamento se desdobre em vários documentos, que devem estar interligados, de modo que cada um reflita um aspecto da Administração Pública, sem que se perca a noção do todo, sendo possível aferir a situação de equilíbrio, déficit ou superávit das contas públicas. Atualmente, também se admite, em face da técnica de orçamento-programa, haver uma pluralidade de leis orçamentárias no tempo, destinadas a fazer do orçamento um instrumento que evidencie a política econômico-financeira e o programa de trabalho do governo.

Compatibiliza-se, dessa forma, o princípio orçamentário da unidade com a existência das leis orçamentárias diferidas no tempo - plano plurianual, lei de diretrizes orçamentárias e anexo de metas fiscais - e com o conteúdo da lei orçamentária que prevê a existência de vários quadros demonstrativos, evidenciando as contas públicas sob diversos aspectos.

Essas considerações são importantes para que se tenha compreensão exata da situação do Poder Judiciário dentro do orçamento público. 
O Brasil adota a forma federativa de organização do Estado e conta com três esferas de governo: a federal, a estadual e a municipal. Todas ficam sujeitas às normas orçamentárias previstas na Constituição e nas leis que veiculam normas gerais de direito financeiro e orçamentário, como é o caso da Lei $n^{\circ} 4.320 / 64$ e da Lei Complementar $n^{\circ}$ 101, de 4.5.2000 (Lei de Responsabilidade Fiscal), devendo, por conseguinte, cada uma das esferas de governo editar as três leis de natureza orçamentária anteriormente referidas.

No que tange ao Poder Judiciário, o Brasil adota o sistema de justiça dual, com órgãos integrantes deste Poder apenas nas esferas federal e estadual, não havendo Poder Judiciário na esfera municipal.

O Poder Judiciário, na lei orçamentária federal, bem como nas estaduais, integra a Administração Pública direta, e a previsão de despesas com esse órgão consta do orçamento fiscal.

As receitas do Poder Judiciário, na forma de organização atualmente adotada, vão constar no orçamento fiscal geral do Governo, não havendo um orçamento de receitas específico para o Poder Judiciário, até para que não se desrespeite o princípio da unidade orçamentária.

Nas classificações adotadas para a elaboração da lei orçamentária, é importante ressaltar as classificações das despesas, pois a técnica de orçamento-programa foca-se nelas para realizar o planejamento e a programação econômico-financeira da unidade considerada.

As despesas do Poder Judiciário vão aparecer sob diversas formas no orçamento, conforme o tipo de classificação da despesa adotada, expostas nos vários quadros previstos no art. $2^{\circ}, \S 1^{\circ}$ da Lei $n^{\circ} 4.320 / 64$, ficando mais evidente na classificação institucional, em que a divisão inicial leva em consideração justamente os três Poderes da República, para em seguida especificarem-se os órgãos e as unidades orçamentárias. 


\subsection{Classificações orçamentárias da despesa pública: as despesas do Poder Judiciário no orçamento}

A atividade governamental é realizada por meio de estruturas administrativas (que podem ser órgãos, unidades orçamentárias ou outras estabelecidas pela organização da Administração Pública), que executam os programas previstos legalmente.

O orçamento público deve ser formulado de modo a facilitar a realização desses programas, sendo fundamental, neste processo, elaborar uma classificação que atenda aos objetivos que o Governo pretende atingir. Jesse Burkhead considera a classificação "a chave estrutural para a organização consciente e racional do orçamento do Governo", identificando quatro objetivos dessa classificação:

a) facilitar a formulação de programas - as contas orçamentárias devem evidenciar claramente os programas, as alterações a serem feitas ao longo do tempo e suas fontes de financiamento;

b) contribuir para a execução efetiva do orçamento - as contas orçamentárias devem propiciar ao administrador as informações acerca do montante de recursos financeiros disponíveis, mecanismos de comparação e demais meios para que possa gerir com eficiência;

c) facilitar a prestação de contas - as contas devem ser organizadas de modo a permitir que outras pessoas verifiquem a aplicação dos recursos; e

d) permitir a análise dos efeitos econômicos - quando as atividades governamentais tiverem responsabilidade pela estabilização econômica e/ ou o desenvolvimento, as contas têm de permitir que se avaliem os efeitos por ela produzidos sobre a economia. ${ }^{113}$

A tarefa de classificar as despesas públicas é bastante complexa, dada a multiplicidade de critérios que se podem adotar para que seja satisfatória e adequadamente realizada, mas, ao mesmo tempo, é fundamental para a elaboração de 
um orçamento que reflita com fidelidade as ações do Governo e a situação das contas públicas. Os vários aspectos da ação governamental que devem ser evidenciados e analisados impedem a utilização de uma classificação única ${ }^{114}$, tornando necessária a adoção de várias classificações simultaneamente, bem como inviabilizando que o orçamento seja uma peça simples de ser compreendida e analisada.

O Manual Técnico de Orçamento Federal explicita de maneira bastante didática o conteúdo das várias classificações adotadas pelo sistema orçamentário brasileiro, em trecho que vale reproduzir:

As classificações orçamentárias permitem a visualização da despesa sob diferentes enfoques ou abordagens, conforme o ângulo que se pretende analisar. Cada uma delas possui uma função ou finalidade específica e um objetivo original que justificam sua criação e pode ser associada a uma questão básica que procura responder.

Resumidamente, temos as seguintes associações:

Estrutura Programática - responde à indagação para que os recursos são alocados? (finalidade)

Classificação Institucional - responde à indagação quem é o responsável pela programação?

Classificação Econômica - a despesa por natureza, responde à indagação o que será adquirido e qual o efeito econômico da realização da despesa?

Classificação Funcional - responde à indagação em que área de ação governamental a despesa será realizada?

A aplicação adequada da estrutura programática e das classificações orçamentárias tem como resultado a configuração de um orçamento onde estariam evidenciados, separadamente:

- o que será implementado,

${ }^{113}$ Orçamento público, p. 145-8.

114 BURKHEAD considera infrutífero e enganoso o esforço para se tentar chegar a uma classificação única (Orçamento público, p. 145). 


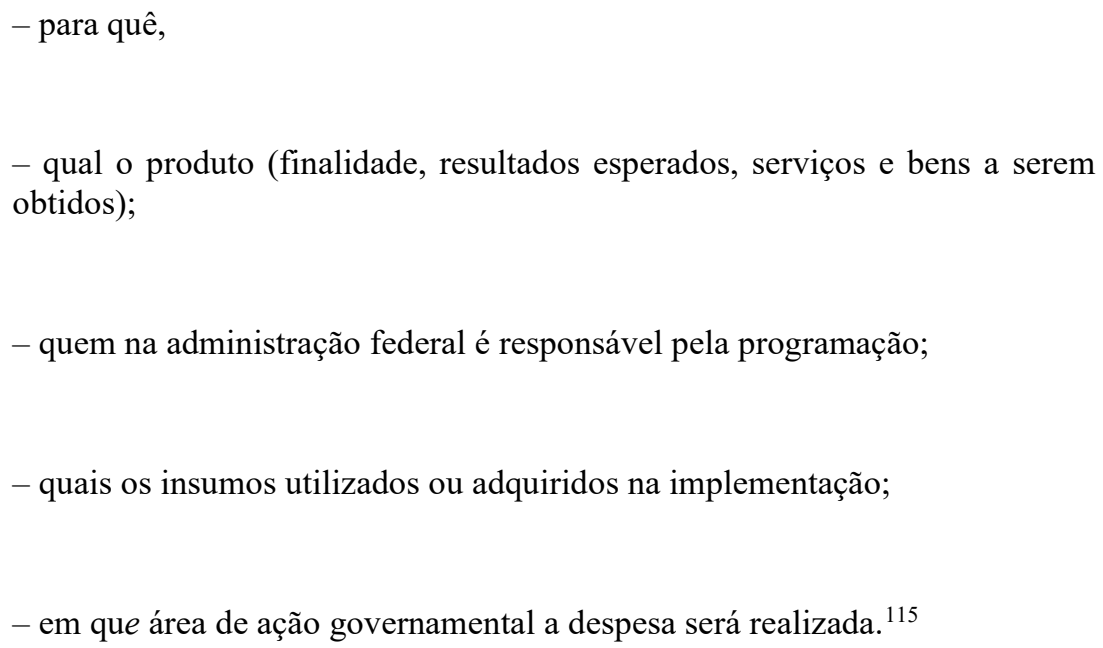

A seguir, serão feitas breves explicações sobre as diversas classificações adotadas pela legislação brasileira, eventualmente enfocando-se os aspectos relacionados ao Poder Judiciário, na ordem em que são apresentadas pela Lei $\mathrm{n}^{\mathrm{o}}$ $4.320 / 64$.

Antes, porém, para a melhor compreensão dos assuntos a serem abordados, cumpre esclarecer os conceitos de dotação orçamentária, crédito orçamentário, célula orçamentária e unidade orçamentária.

Dotação "deve ser a medida, ou quantificação monetária do recurso aportado a um programa, atividade, projeto, categoria econômica ou objeto de despesa". ${ }^{116}$

Crédito orçamentário é “a autorização através de lei de orçamento ou de créditos adicionais, para a execução de programa, projeto ou atividade ou para o desembolso de quantia aportada a objeto de despesa, vinculado a uma categoria econômica, e, pois, a um programa. Assim, o crédito orçamentário seria portador de uma dotação e está o limite autorizado, quantificado monetariamente". ${ }^{117}$

Célula orçamentária é um conceito informal, que vem se desenvolvendo em razão dos modernos sistemas de administração financeira (SIAFI e SIAFEM, por

\footnotetext{
${ }^{115}$ BRASIL, Ministério do Planejamento. Manual técnico de orçamento, p. 38.

${ }^{116}$ MACHADO JÚNIOR; REIS, A Lei 4.320 comentada, p. 21. Ou, segundo José Afonso da Silva, dotação é a "consignação de recursos no orçamento para o atendimento de qualquer despesa e também para as despesas totais dos órgãos do Governo (legislativos, executivos e judiciários) e da administração (Ministérios, organismos autônomos, departamentos etc.)" (Orçamento-programa .., p. 314).
} 
exemplo); é a classificação que vai desde o órgão, unidade orçamentária, até a fonte de recursos. ${ }^{118}$

Unidade orçamentária é "o agrupamento de serviços subordinados ao mesmo órgão ou repartição a que serão consignadas dotações próprias” (Lei 4.320/64, art. 14). Este conceito será visto em mais detalhes no item 4.3.2.

\subsubsection{Classificação por categorias econômicas}

A classificação econômica, ou classificação por categorias econômicas, permite vislumbrar informações úteis do ponto de vista macroeconômico, evidenciando os efeitos das despesas públicas sobre a economia e sobre o produto nacional.

A classificação por categorias econômicas consta dos arts. 12 a 21 da Lei $n^{\circ}$ 4.320/64, que preveem duas categorias e cinco subcategorias - e estas, por sua vez, contêm a discriminação por elementos. Esta lei exige que a lei orçamentária discrimine a despesa por elementos (art. 15). Elementos correspondem ao "desdobramento da despesa com pessoal, material, serviços, obras e outros meios de que se serve a administração pública para consecução dos seus fins" (Lei no 4.320/64, art. 15, $\S 1^{\circ}$ ).

As duas categorias econômicas são as despesas correntes e as despesas de capital.

As despesas correntes são "os gastos de natureza operacional realizados pela administração pública, para a manutenção e funcionamento dos seus órgãos". ${ }^{119}$

As despesas de capital são "os gastos realizados pela administração pública, cujo propósito é o de criar novos bens de capital ou mesmo adquirir bens de capital já em uso, como é o caso dos investimentos e inversões financeiras, respectivamente, e que constituirão, em última análise, incorporações ao patrimônio público de forma efetiva ou através de mutação patrimonial". ${ }^{120}$

\footnotetext{
${ }^{117}$ MACHADO JÚNIOR; REIS, A Lei 4.320..., p. 21.

${ }^{118}$ SILVA; VASCONCELOS, Manual de execução orçamentária e contabilidade pública, p. 32.

${ }^{119}$ KOHAMA, Contabilidade pública, p. 111.

${ }^{120}$ Idem, p. 111.
} 
A classificação até o nível de elementos obedece ao seguinte esquema, nos termos do art. 13 da Lei $\mathrm{n}^{\circ} 4.320 / 64$ [CATEGORIA ECONÔMICA: Subcategoria econômica (elemento, elemento)]:

DESPESAS CORRENTES: Despesas de custeio (pessoal civil, pessoal militar, material de consumo, serviços de terceiros, encargos diversos); Transferências correntes (subvenções sociais, subvenções econômicas, inativos, pensionistas, saláriofamília e abono familiar, juros da dívida pública, contribuições da previdência social, diversas transferências correntes).

DESPESAS DE CAPITAL: Investimentos (obras públicas, serviços em regime de programação especial, equipamentos e instalações, material permanente, participação em constituição ou aumento de capital de empresas ou entidades industriais ou agrícolas); Inversões financeiras (aquisição de imóveis, participação em constituição ou aumento de capital de empresas ou entidades comerciais ou financeiras, aquisição de títulos representativos de capital de empresas em funcionamento, constituição de fundos rotativos, concessão de empréstimos, diversas inversões financeiras); Transferência de capital (amortização da dívida pública, auxílios para obras públicas, auxílios para equipamentos e instalações, auxílios para inversões financeiras, outras contribuições).

Esse esquema de especificação da despesa deve ser observado em cada unidade administrativa ou órgão de governo (Lei $\mathrm{n}^{\mathrm{o}}$ 4.320/64, art. 13, caput), abrangendo, portanto, o Poder Judiciário.

A classificação da despesa segundo as categorias econômicas consta expressamente da lei orçamentária, nos termos do art. $2^{\circ}, \S 1^{\circ}$, II, e Anexo 1 , da Lei $n^{\circ}$ $4.320 / 64$.

\subsubsection{Classificação institucional}

A classificação institucional leva em consideração a unidade responsável pela execução da despesa. Esta classificação apresenta especial relevância para o presente trabalho, pois é nela que se identifica claramente o Poder Judiciário no contexto 
orçamentário. E consta obrigatoriamente da lei orçamentária, conforme previsto pelo art. $2^{\circ}, \S 1^{\circ}$, IV, da Lei $n^{\circ} 4.320 / 64$.

O processo de elaboração e execução orçamentária, tema que será visto nos itens 4.4 e 4.5, tem como agentes responsáveis o órgão central de orçamento ${ }^{121}$, os órgãos setoriais e as unidades orçamentárias, evidenciando a importância da classificação institucional para todo o ciclo orçamentário.

Nas esferas federal e estaduais, a classificação institucional é feita inicialmente pela divisão nos três poderes: Legislativo, Judiciário e Executivo, os quais podem ser divididos em órgãos, ou considerados como tais. Os órgãos, por sua vez, são subdivididos em unidades orçamentárias.

O conceito de unidade orçamentária, ao qual já foi feita breve referência anteriormente, é de fundamental importância. Segundo o art. 14 da Lei $n^{\circ}$ 4.320/64, como já mencionado, "constitui unidade orçamentária o agrupamento de serviços subordinados ao mesmo órgão ou repartição a que serão consignadas dotações próprias"; é "o órgão ou agrupamento de serviços com autoridade para movimentar dotações", na apropriada síntese de Machado Jr. e Costa Reis ${ }^{122}$; trata-se do "menor nível da classificação institucional, agrupada em órgãos orçamentários, entendidos estes como os de maior nível da classificação institucional" ${ }^{123}$. A unidade orçamentária é o centro de planejamento, elaboração orçamentária, execução orçamentária, controle interno e de verificação de custos e resultados, tornando-se responsável pelo planejamento e pela execução de projetos e atividades, sendo competente para autorizar e/ou empenhar despesas. ${ }^{124}$ A unidade orçamentária permite maior eficiência na descentralização das tarefas a serem realizadas com as dotações a ela destinadas.

$\mathrm{Na}$ esfera federal, o Poder Judiciário brasileiro tem como órgãos o Supremo Tribunal Federal, o Superior Tribunal de Justiça, a Justiça Federal, a Justiça Militar, a Justiça Eleitoral, a Justiça do Trabalho e a Justiça do Distrito Federal e Territórios.

\footnotetext{
${ }^{121} \mathrm{Na}$ esfera federal, é a Secretaria de Orçamento Federal do Ministério do Planejamento, Orçamento e Gestão (SOF).

${ }^{122}$ A Lei $4.320 \ldots$, p. 55.

${ }^{123}$ Lei Federal no 10.934, de 11.8.2004 (Lei de Diretrizes Orçamentárias para 2005), art. 4º VI.

${ }^{124}$ MACHADO JÚNIOR; REIS. A Lei 4.320..., p. 55.
} 
Esses órgãos podem ser divididos em unidades orçamentárias, como é o caso, por exemplo, da Justiça Federal, que tem seis unidades orçamentárias: Justiça Federal de primeira instância, TRF da $1^{\mathrm{a}}$ Região, TRF da $2^{\mathrm{a}}$ Região, TRF da $3^{\mathrm{a}}$ Região, TRF da $4^{\text {a }}$ Região e TRF da $5^{\text {a }}$ Região. O mesmo ocorre com a Justiça do Trabalho, que tem 25 unidades orçamentárias: o Tribunal Superior do Trabalho (TST) e os 24 Tribunais Regionais do Trabalho. Há órgãos compostos de apenas uma unidade orçamentária, como o Supremo Tribunal Federal, o Superior Tribunal de Justiça e a Justiça Militar da União.

No caso do Estado de São Paulo, a Lei Estadual $n^{0} 11.816$, de 30.12.2004 (orçamento para o exercício de 2005), prevê, em seu orçamento físcal, o Poder Judiciário (item 4.2 do orçamento), que tem como unidades orçamentárias o Tribunal de Justiça (código 03000), o Primeiro Tribunal de Alçada Civil (código 04000), o Tribunal de Alçada Criminal (código 05000), o Tribunal de Justiça Militar (código 06000) e o Segundo Tribunal de Alçada Civil (código 22000). Essa classificação foi alterada no exercício financeiro de 2006, tendo em vista a extinção dos Tribunais de Alçada, medida implementada em decorrência da promulgação da Emenda Constitucional 45, de 2004. Atualmente são apenas duas as unidades orçamentárias: Tribunal de Justiça (03000) e Tribunal de Justiça Militar (06000) (Lei 12.298/06 - orçamento de 2006).

\subsubsection{Classificação funcional e por programas}

A adoção da técnica de orçamento-programa trouxe inovações e modernizou a forma de apresentação dos orçamentos, dando origem à classificação funcional e por programas, que enfatiza os objetivos do Governo, vinculando os gastos públicos aos programas que se pretende desenvolver. Confere maior transparência às atividades governamentais, incentivando e facilitando a fiscalização dos atos e a cobrança de resultados.

A Lei $n^{\circ} 4.320 / 64$, ao estabelecer em seu art. $2^{\circ}$ que a Lei de Orçamento deverá evidenciar a política econômico-financeira e o programa de trabalho do Governo, contendo o sumário da despesa por funções do Governo (art. $2^{\circ}, \S 1^{\circ}$, I) e estabelecendo a discriminação da despesa pela classificação funcional, nos termos do Anexo 5 (art. $8^{\circ}$, 
$\S 2^{\circ}$ ), adotou claramente a técnica de orçamento-programa, fazendo da classificação funcional e por programas a mais relevante do orçamento.

O Anexo 5 da Lei $n^{\circ} 4.320 / 64$, com a atualização dada pela Portaria 42 do Ministério do Orçamento e Gestão ${ }^{125}$, de 1999, especifica o conteúdo e a forma da classificação funcional e por programas.

Nessa classificação, as ações governamentais passam a ser classificadas e identificadas em termos de funções e subfunções, programas, projetos, atividades e operações especiais.

Função corresponde ao maior nível de agregação das diversas áreas do setor público (Portaria 42, art. $1^{\circ}, \S 1^{\circ}$ ). Subfunção é uma partição da função que agrega determinado subconjunto do setor público $\left(\S 3^{\circ}\right)$.

Programa é o instrumento de organização da ação governamental visando à concretização dos objetivos pretendidos (Portaria 42, art. $2^{\circ}$, $a$; Lei $n^{\circ} 10.934 / 004$, art. $\left.4^{\mathrm{o}}, \mathrm{I}\right)$.

Cada programa contém um objetivo, indicador que quantifica a situação que o programa tenha por fim modificar e os produtos (bens e serviços) necessários para atingir o objetivo. A partir do programa são identificadas as ações, sob a forma de atividades, projetos ou operações especiais, especificando os respectivos valores e metas e as unidades orçamentárias responsáveis pela realização da ação. A cada projeto ou atividade só poderá estar associado um produto, que, quantificado por sua unidade de medida, dará origem à meta. ${ }^{126}$

O Decreto $\mathrm{n}^{\circ}$ 2.829, de 1998, ao estabelecer normas para a elaboração e execução das leis orçamentárias na esfera federal, determina que toda ação finalística do governo federal seja estruturada em forma de programas (art. $1^{\circ}$ ).

Projeto é o instrumento de programação destinado a alcançar o objetivo de um programa, que compreende um conjunto de operações, em um período determinado, que resultam em um produto voltado à expansão ou ao aperfeiçoamento da ação de governo (Portaria 42, art. $2^{\circ}, b$; Lei $\mathrm{n}^{\circ} 10.934 / 04$, art. $4^{\circ}$, III).

\footnotetext{
${ }^{125}$ Atual Ministério do Planejamento, Orçamento e Gestão.

${ }^{126}$ BRASIL, Ministério do Planejamento, Manual técnico de orçamento..., p. 8.
} 
Já a atividade corresponde a um instrumento de programação que visa alcançar um objetivo de um programa, envolvendo um conjunto de operações contínuas e permanentes, das quais resulta um produto necessário à manutenção do Governo (Portaria 42, art. $2^{\circ}, c$; Lei no 10.934/04, art. $4^{\circ}$, II).

Operações especiais é uma categoria que engloba as despesas que não contribuem para a manutenção das ações de governo, das quais não resulta um produto, e não geram contraprestação sob a forma de bem ou serviço (Portaria 42 , art. $2^{\circ}, d$; Lei $n^{\mathrm{o}} 10.934 / 04$, art. $\left.4^{\mathrm{o}}, \mathrm{IV}\right)$.

Os programas poderão ser divididos em subprogramas. Esses, em cada área de Governo, serão obrigatoriamente desdobrados em projetos e atividades (Portaria SOF 9, de 28.1.1974). A Lei de Diretrizes Orçamentárias da união para 2005 ( $\mathrm{n}^{\mathrm{o}}$ 10.934/04) prevê ainda a categoria do subtítulo, que corresponde ao menor nível da categoria de programação, devendo ser utilizado para especificar a localização física da ação.

No caso do Poder Judiciário, o Anexo 5, atualizado, prevê, entre as funções, a categoria "judiciária", atribuindo-lhe o número classificatório 02, dividindo-a nas subfunções "ação judiciária" (061) e "defesa do interesse público no processo judiciário" (062). Há ainda funções também relacionadas à atividade jurisdicional, como a função "essencial à justiça" (03), que se divide nas subfunções "defesa da ordem jurídica" (091) e "representação judicial e extrajudicial" (092).

No Estado de São Paulo, o orçamento para o exercício de 2005 (Lei Estadual n ${ }^{\circ}$ 11.816/04), em seu quadro VI (demonstrativo da despesa por função, subfunção e programa, conforme o vínculo de recursos) prevê a função "judiciária” (02), dividida nas subfunções “ação judiciária” (061), "representação judicial e extrajudicial” (092), “administração geral” (122), "tecnologia da informação" (126), "formação de recursos humanos" (128), "previdência do regime estatutário" (272) e "outros encargos especiais" (846). Cada uma dessas subfunções abrange um ou vários programas.

É importante notar, a partir desse exemplo, que não há uma correspondência absoluta entre a "função judiciária" (classificação funcional e por programas) e o "Poder Judiciário" (classificação institucional), o que mostra a independência das diversas 
classificações orçamentárias, indicando que cada uma tem por finalidade evidenciar um aspecto da despesa pública.

No caso mencionado, do orçamento do Estado de São Paulo, as subfunções "representação judicial e extrajudicial" (092) e "administração geral" (122), que integram a função "judiciária" (02), abrangem programas vinculados ao órgão "Procuradoria do Estado" (40000), que integra o Poder Executivo.

A subfunção "previdência do regime estatutário" (272), embora se refira a despesas vinculadas a unidades orçamentárias do Poder Judiciário (Tribunal de Justiça, Primeiro Tribunal de Alçada Civil, Tribunal de Alçada Criminal, Tribunal de Justiça Militar e Segundo Tribunal de Alçada Civil), integra o programa “obrigações previdenciárias" (0101).

Os programas podem variar a cada orçamento, tendo em vista que as demandas por bens e serviços, que a sociedade deseja ver atendidas, alteram-se ao longo do tempo.

Para citar um exemplo de programa, utilizando o mesmo orçamento do Estado de São Paulo para o exercício de 2005, existe, entre os vários programas relacionados ao Poder Judiciário, o programa "Processo Judiciário no Tribunal de Justiça" (0303). ${ }^{127}$ É um programa vinculado ao órgão Tribunal de Justiça (03000), que tem como objetivo "ampliar e modernizar a prestação jurisdicional em $1^{\mathrm{a}}$ e $2^{\mathrm{a}}$ instâncias às causas que tratam da capacidade e estado das pessoas", sendo seu público-alvo "o cidadão que recorre à Justiça", englobando cinco ações: "diligências judiciais" (4567), "criação e instalação de seções do Tribunal de Justiça no interior" (4825), "distribuição da Justiça" (4826), "informatização" (4827) e "instalação de varas judiciais" (4828). Cada uma dessas ações apresenta um produto, uma meta e o valor orçamentário correspondente. A ação "instalação de varas judiciais", por exemplo, tem como produto "varas instaladas", mensuradas em termos de unidades (cada unidade corresponde a uma vara instalada). A meta prevista para esta ação é 25 , ou seja, pretende-se instalar 25 varas no exercício financeiro de 2005 . O valor previsto para esta ação é de $\mathrm{R} \$ 2.640 .324,00$, a qual viabiliza um programa por meio de um projeto, por envolver um conjunto de operações limitadas no tempo, das quais resultam produtos as varas instaladas, como também ocorre com a ação "criação e instalação de seções do Tribunal de Justiça no interior". Já a ação "distribuição da Justiça" tem como instrumento de programação uma atividade, por envolver um conjunto de operações que se realizam de modo contínuo e permanente.

${ }^{127}$ Quadro IV - demonstrativo da despesa por programa. 
Além desse, há outros programas vinculados ao Poder Judiciário no orçamento do Estado de São Paulo de 2005, tais como: "processo judiciário no Primeiro Tribunal de Alçada Civil” (0401), "processo judiciário no Tribunal de Alçada Criminal” (0501), "processo judiciário militar" (0600) e "processo judiciário no Segundo Tribunal de Alçada Civil” (2201).

Há casos em que despesas de interesse do Poder Judiciário integram programas a ele não vinculados, considerada a classificação institucional, o que suscita questões importantes para a discussão acerca da autonomia deste Poder.

Um exemplo que evidencia isso de maneira inequívoca pode ser extraído do mesmo orçamento que vem sendo analisado (Lei Estadual de São Paulo n ${ }^{\circ}$ 11.816/04). Trata-se do programa "Construção, ampliação e reforma de edificações forenses do Judiciário" (1717), cujo objetivo é "dotar as comarcas de edificações forenses adequadas à prestação de serviços com qualidade", e tem como ação "construção, ampliação e reforma de fóruns" (1430). Este é um programa vinculado ao órgão "Justiça" (17000), que, na classificação institucional, corresponde à Secretaria da Justiça e Defesa da Cidadania, a qual é integrante do Poder Executivo.

O fato de - ao menos no Estado de São Paulo, em que essa forma de organização governamental é adotada - atribuir-se à Secretaria da Justiça e Defesa da Cidadania a função de construir, reformar e conservar os edifícios dos fóruns gera algumas distorções na apresentação e consequente interpretação do orçamento. Isso porque, ao analisar-se o Poder Judiciário no orçamento, ver-se-á que praticamente não há despesas de capital, mas tão somente despesas correntes (considerada a classificação por categorias econômicas), o que pode fazer crer não estarem sendo feitos investimentos na área do Poder Judiciário. Mas essa será uma impressão falsa, pois os investimentos na área do Poder Judiciário, que se constituiriam fundamentalmente em construções de edificações para abrigar fóruns e varas, não vão aparecer no orçamento do Poder Judiciário (analisando-se a classificação institucional), e sim no do Poder Executivo, por estarem na esfera de atribuição da Secretaria da Justiça e Defesa da Cidadania, órgão integrante do Poder Executivo. 
Esse fato também produz efeitos significativos na autonomia administrativa e financeira do Poder Judiciário. Como foi visto, há a previsão orçamentária de recursos para o programa "Processo judiciário no Tribunal de Justiça" (0303) destinados ao projeto "instalação de varas judiciais" (4828). No entanto, muitas dessas varas judiciais a serem instaladas dependem de construção de edificações forenses nas quais serão abrigadas. Os recursos para isso estão previstos no projeto "construção, ampliação e reforma de fóruns" (1430), integrante do programa "Construção, ampliação e reforma de edificações forenses do Judiciário" (1717), vinculado ao órgão "Justiça" (17000). ${ }^{128}$ Consequentemente, parte do cumprimento do projeto de instalação de varas judiciais, sob o comando do Poder Judiciário, fica vinculado à prévia realização de projetos gerenciados pelo Poder Executivo.

Nesse caso, a perda de autonomia administrativa e financeira do Poder Judiciário resulta, em parte, da organização da Administração Pública, que atribuiu a órgão do Poder Executivo tarefa de interesse direto do Poder Judiciário. Outra parte é responsabilidade da elaboração e organização do orçamento público, que criou um programa intrinsecamente ligado ao Poder Judiciário e o vinculou ao Poder Executivo. A solução desta questão envolve necessariamente uma decisão política a ser tomada no sentido de serem feitas as alterações na Administração Pública e no orçamento com a finalidade de corrigir essa distorção. A manutenção dessa situação é prejudicial por várias razões. Primeiro, porque produz uma equivocada visão do Poder Judiciário ao se analisar o orçamento, pois deixam de ser identificados os investimentos realizados com a construção, ampliação e reforma de fóruns nas despesas do Poder Judiciário. Segundo, porque reduz a autonomia administrativa e financeira do Poder Judiciário, que passa a depender do Poder Executivo nas questões relacionadas à construção, ampliação e reforma de edificações, o que está em desacordo com o princípio da separação de poderes e com a autonomia administrativa e financeira do Poder Judiciário, previstas nos arts. $2^{\circ}$ e 99 da CF. Terceiro, porque vincula o cumprimento de um programa, sob a gerência do Poder Judiciário, à conclusão prévia de um projeto administrado por outro Poder, diminuindo a eficiência do programa, dados os diversos problemas decorrentes dessa administração conjunta e dependente, por órgãos e sistemas administrativos diferentes.

${ }^{128}$ Poder Executivo - Secretaria da Justiça e Defesa da Cidadania. 
O mesmo não ocorre em outras administrações. Na esfera federal, por exemplo, havia a previsão, no orçamento da união para 2004 (Lei $n^{0}$ 10.837/04), do projeto “Construção do Edifício-Sede da Seção Judiciária em Cuiabá-MT - no município de Cuiabá-MT” (classificação funcional programática 05697241 0101), vinculada ao órgão "Justiça Federal” (12000) e à unidade orçamentária “Tribunal Regional Federal da $1^{\text {a }}$ Região" (12102), que integram o Poder Judiciário. Essa previsão se manteve no orçamento da união para 2005 (Lei no 11.100/05).

\subsection{A elaboração do orçamento}

A análise da autonomia financeira do Poder Judiciário requer um estudo sobre as fases de elaboração das leis orçamentárias, uma vez que o mecanismo pelo qual se operacionaliza este procedimento é fundamental na avaliação do grau de autonomia que se confere ao Poder Judiciário, principalmente para a decisão a respeito de suas despesas.

O sistema de organização das contas públicas no Brasil prevê, como já mencionado, a existência de três leis de natureza orçamentária que se coordenam de forma a assegurar o planejamento da ação governamental.

O plano plurianual (PPA) é elaborado no primeiro ano do mandato do chefe do Poder Executivo, devendo o projeto ser encaminhado por ele ao Poder Legislativo até o dia 31 de agosto (quatro meses antes do encerramento do primeiro exercício financeiro) e devolvido por esse para sanção até o encerramento da sessão legislativa. Uma vez promulgado, o plano plurianual é válido por quatro anos (até o final do primeiro ano de mandato do sucessor), segundo as normas atualmente em vigor (CF, arts. 82 e 165, I; ADCT, art. $35, \S 2^{\circ}$, I; e Lei $\mathrm{n}^{\circ} 4.320 / 64$, art. 34). Nele constarão as diretrizes, os objetivos e as metas da Administração Pública para o período mencionado, no que se refere às despesas de capital e aos programas de duração continuada.

A lei de diretrizes orçamentárias (LDO) é elaborada anualmente, devendo o projeto ser encaminhado pelo chefe do Executivo ao Poder Legislativo até o dia 15 de abril (oito meses e meio antes do encerramento do exercício financeiro) e devolvido por esse para sanção até o encerramento do primeiro período da sessão legislativa $(\mathrm{CF}$, art. 
165, II; ADCT, art. 35, § $2^{\circ}$, II; e Lei $n^{\circ} 4.320 / 64$, art. 34). A LDO tem por função orientar a elaboração da lei orçamentária anual, estabelecendo, basicamente, as metas e as prioridades da Administração Pública para o exercício financeiro seguinte.

A lei orçamentária (LOA) também é anual, devendo o chefe do Poder Executivo encaminhar o projeto de lei ao Poder Legislativo até o dia 31 de agosto (quatro meses antes do encerramento do primeiro exercício financeiro) e devolvido por esse para sanção até o encerramento da sessão legislativa $\left(\mathrm{CF}\right.$, art. 165, § 5\% $\mathrm{ADCT}$, art. 35, § $2^{\circ}$, III; e Lei n 4.320/64, art. 34).

A lei orçamentária deve ser preparada de acordo com o que foi estabelecido na lei de diretrizes orçamentárias e deve ser compatível com o plano plurianual, coordenando-se, assim, o sistema de planejamento da ação governamental por meio das leis orçamentárias. ${ }^{129}$

O ciclo orçamentário, que corresponde ao período em que se processam atividades peculiares ao processo orçamentário, como a preparação, a votação e a execução ${ }^{130}$, compreende um processo de elaboração da lei orçamentária no sentido "de baixo para cima", ou seja, das unidades orçamentárias, que gerenciam os programas e as respectivas despesas, para os órgãos setoriais, e desses para o órgão central, que vai consolidar as propostas apresentadas e definir o projeto de lei orçamentária a ser enviado ao Poder Legislativo. Paralelamente, há um processo de elaboração da lei orçamentária no sentido "de cima para baixo", que se inicia com a fase da definição de "macrodiretrizes", em que são analisados e estabelecidos os parâmetros, as metas e os riscos fiscais, bem como os objetivos das políticas governamentais nas áreas de moeda, crédito e câmbio, tendo-se em vista o disposto na lei de diretrizes orçamentárias. ${ }^{131}$

Far-se-á, inicialmente, um estudo sobre o processo de elaboração da lei orçamentária anual da união, por ser o mais complexo e completo, e, havendo relevância em algum aspecto, poderá ser feita referência às fases de elaboração das leis orçamentárias estaduais e municipais. Pretende-se evitar com isso repetição

\footnotetext{
${ }^{129}$ LC 101/00 (LRF), art. 5 . A Constituição Federal, no art. 166, § $3^{\circ}$, impede a aprovação de emendas à lei orçamentária incompatíveis com o plano plurianual e com a lei de diretrizes orçamentárias.

${ }^{130}$ SILVA, José Afonso da. Orçamento-programa, p. 229-30.

${ }^{131}$ BRASIL, Ministério do Planejamento, Manual técnico de orçamento..., p. 51.
} 
desnecessária de procedimentos que, no mais das vezes, são semelhantes e nada acrescentarão ao objeto central deste trabalho.

Também para evitar repetições da mesma natureza, partir-se-á do pressuposto, no processo de elaboração da lei orçamentária, da existência do plano plurianual e da lei de diretrizes orçamentárias. Essas leis, embora possam divergir da lei orçamentária quanto a prazos e mesmo quanto a algumas etapas do sistema de elaboração, em sua maior parte apresentam mecanismos semelhantes, sendo mais útil e menos redundante a menção eventual a aspectos que possam interessar do que a descrição dos processos referentes a cada uma dessas leis. ${ }^{132}$

O processo de elaboração das leis orçamentárias pode ser dividido em duas fases: a primeira, a qual denominaremos fase administrativa, compreende as etapas de elaboração e formalização das propostas, até que se chegue ao produto final, que é o projeto de lei orçamentária a ser encaminhado ao Poder Legislativo; e a segunda, a fase legislativa, que corresponde à tramitação do projeto enviado pelo chefe do Executivo dentro do Poder Legislativo, até a aprovação final, culminando com a promulgação da lei orçamentária anual.

No Brasil, o ciclo orçamentário, abrangendo os processos de elaboração e de execução das leis orçamentárias, é realizado por meio de sistemas informatizados, que, na esfera federal, têm como principal ferramenta o SIAFI (Sistema Informatizado de Administração Financeira do governo federal). O SIAFI surgiu em 1986, com a criação da Secretaria do Tesouro Nacional (STN), a qual, tendo como missão auxiliar o Ministério da Fazenda na execução de um orçamento unificado, desenvolveu e implantou o sistema, que passou a vigorar em janeiro do ano seguinte. ${ }^{133}$ Alguns países implantaram sistema semelhante, como o SIDIF (Sistema Integrado de Información Financiera), na Argentina, e o SIC'2 (Sistema de Información Contable y Presupuestaria), na Espanha. ${ }^{134}$

\footnotetext{
$132 \mathrm{O}$ processo de elaboração das leis orçamentárias encontra base legal em: CF, arts. 165 a 167; Lei de Responsabilidade Fiscal, arts. $3^{\circ}$ a $5^{\circ}$; Lei $n^{\circ} 4.320 / 64$, arts. 22 a 46; Decreto-Lei $n^{\circ}$ 200/67, arts. 15 e 16; Lei $\mathrm{n}^{\circ} 10.180 / 01$, arts. $1^{\circ}$ a $8^{\circ}$; Decreto $\mathrm{n}^{\mathrm{o}}$ 2.829/98; Portaria MOG 42/99 e Portaria Interministerial $163 / 01$.

${ }^{133}$ Disponível em: www.stn.fazenda.gov.br/siafi. Acesso em: 11.9.2004.

${ }^{134}$ PETREI, Budget and Control.
} 


\subsubsection{Fase administrativa}

A elaboração do orçamento federal, na fase administrativa, envolve agentes de três naturezas: o órgão central, os órgãos setoriais e as unidades orçamentárias.

O Ministério do Planejamento, Orçamento e Gestão, por meio da Secretaria de Orçamento Federal (SOF), é responsável pela coordenação, consolidação e elaboração da proposta orçamentária da união, exercendo a função de órgão central. Os órgãos setoriais têm a responsabilidade de fazer o levantamento das despesas necessárias em suas respectivas áreas, e as unidades orçamentárias, já vistas anteriormente no item 4.3.2, devem avaliar os programas e respectivos custos sob sua gestão. ${ }^{135}$

Para fins orçamentários, o Poder Judiciário, na esfera federal, para o exercício de 2004, tem sete órgãos (STF, STJ, Justiça Federal, Justiça Militar da união, Justiça Eleitoral, Justiça do Trabalho e Justiça do Distrito Federal e dos Territórios), com 65 unidades orçamentárias, distribuídas da seguinte forma (órgão - número de unidades orçamentárias): STF - 1; STJ - 1; Justiça Federal - 6; Justiça Militar da união - 1; Justiça Eleitoral - 28; Justiça do Trabalho - 25; Justiça do Distrito Federal e dos Territórios - 2; e um fundo (Fundo Partidário). ${ }^{136}$ Para ilustrar essa organização do Poder Judiciário na esfera federal, utilizaremos o órgão setorial Justiça Federal, o qual é composto, como mencionado, por seis unidades orçamentárias (TRF da $1^{\mathrm{a}}$ Região, TRF da $2^{\mathrm{a}}$ Região, TRF da $3^{\mathrm{a}}$ Região, TRF da $4^{\mathrm{a}}$ Região, TRF da $5^{\mathrm{a}}$ Região e a Justiça Federal de primeiro grau), cabendo ao Conselho da Justiça Federal coordenar a elaboração do orçamento do setor.

As unidades orçamentárias podem ter unidades administrativas destinadas a melhor organizar seus serviços. Essas unidades coordenam o processo de elaboração da proposta orçamentária no seu âmbito de atuação, integrando e articulando o trabalho das unidades administrativas componentes. São responsáveis pela apresentação da programação orçamentária detalhada da despesa por programa, ação orçamentária e

\footnotetext{
${ }^{135}$ BRASIL, Ministério do Planejamento, Manual técnico de orçamento, p. 15.

${ }^{136}$ Fundo Especial de Assistência Financeira aos Partidos Políticos, previsto nos arts. 38 e seguintes da Lei ${ }^{\circ} 9.096 / 95$.
} 
subtítulo, devendo estabelecer suas diretrizes, fixar as prioridades, consolidar e formalizar a respectiva proposta orçamentária. ${ }^{137}$

Identificam-se três etapas no processo de elaboração orçamentária, em sua fase administrativa: a etapa preliminar, a etapa intermediária e a etapa final.

\subsubsection{Etapa preliminar}

$\mathrm{Na}$ etapa preliminar, o órgão central de planejamento, que na esfera federal corresponde ao Ministério do Planejamento, Orçamento e Gestão (Lei nº 10.180/01, art. $\left.4^{\mathrm{o}}, \mathrm{I}\right)$, elabora as diretrizes e fixa as normas gerais para a elaboração do orçamento federal. É feito um planejamento do processo de elaboração, com a definição das etapas, agentes responsáveis, cronograma e instruções necessárias, para, em seguida, estabelecerem-se as prioridades e as metas, bem como elaborar-se a estrutura programática. Faz-se, então, o cálculo das receitas estimadas, o que permite passar à fase seguinte, de fixação dos referenciais monetários, os quais serão enviados aos órgãos setoriais, para que, com base neles, sejam elaboradas as respectivas propostas orçamentárias.

A estimativa da receita a ser arrecadada é uma questão complexa, pois envolve previsões de arrecadação de tributos e também receitas de outras fontes, cujos valores estão sujeitos, na maior parte dos casos, às variações do comportamento do mercado nacional e internacional, além de conjunturas políticas e outras circunstâncias difíceis de se prever com precisão, tais como câmbio, juros, inflação, crescimento da economia, nível de endividamento e outros. Dependem de informações de outros órgãos, em especial daqueles ligados à arrecadação tributária, como o Ministério da Fazenda, bem como todos os demais que tenham fontes próprias de arrecadação. Além disso, há divergências quanto aos critérios a serem adotados em diversos aspectos da elaboração desses cálculos. A estimativa da receita pública, a par das dificuldades enfrentadas, é de grande relevância para a elaboração orçamentária, pois os valores nela previstos servirão de base para a fixação das despesas públicas e, consequentemente, para o cálculo das dotações a cada um dos programas existentes.

${ }^{137}$ BRASIL, Ministério do Planejamento, Manual técnico de orçamento, p. 15-6. 
A fixação dos referenciais monetários para a apresentação das propostas orçamentárias setoriais, no caso do Poder Judiciário, obedece a diretrizes estabelecidas previamente na lei de diretrizes orçamentárias, nos termos do $\S 1^{\circ}$ do art. 99 da CF..$^{138}$

Para exemplificar, na lei de diretrizes orçamentárias (LDO) da união para 2005 (Lei $\left.{ }^{\circ} 10.934 / 04\right)$, que contém as diretrizes para a elaboração do orçamento de 2005, foi estabelecido, no art. 17, que o Poder Judiciário terá como parâmetro para suas despesas $^{139}$ o conjunto das dotações fixadas na lei orçamentária de 2004, com as alterações decorrentes dos créditos suplementares e especiais, aprovados até 30.6.2004. O que se observa, em regra, é que as leis de diretrizes orçamentárias da união vêm mantendo redação semelhante neste ponto, estabelecendo este padrão de limite de despesas para o Poder Judiciário. Ou seja: basicamente, o Poder Judiciário tem como limite de despesas, fixado pela lei de diretrizes orçamentárias, o mesmo valor do ano anterior, com as alterações que ocorreram no decorrer do exercício e eventuais acréscimos para despesas não ordinárias já previstas. O mesmo art. 17 (LDO para 2005) já estabelece alguns acréscimos a esse montante, como a inclusão das despesas com manutenção de imóveis cuja aquisição ou conclusão esteja prevista para os exercícios de 2004 e 2005, a implantação de novas varas e juizados especiais federais, bem como as despesas necessárias para a realização do referendo popular sobre a proibição e a comercialização de armas de fogo.

Cumpre notar que o mecanismo para a elaboração do orçamento, da forma como vem sendo utilizado no Brasil, não adota a técnica do "orçamento base zero", que tem como fundamento a obrigatoriedade do administrador de justificar todos os recursos pleiteados. ${ }^{140} \mathrm{O}$ que se observa é a manutenção dos gastos que já vinham sendo feitos em exercícios anteriores, justificando-se tão somente os incrementos incorporados ao

\footnotetext{
138 “Art. 99. Ao Poder Judiciário é assegurada autonomia administrativa e financeira. $\S 1^{\circ}$ - Os tribunais elaborarão suas propostas orçamentárias dentro dos limites estipulados conjuntamente com os demais Poderes na lei de diretrizes orçamentárias". (grifo nosso).

${ }^{139}$ Despesas classificadas nos grupos de natureza de despesa: 3 - Outras Despesas Correntes, 4 - Investimentos e 5 - Inversões Financeiras, em 2004.

${ }^{140} \mathrm{O}$ orçamento base zero "é um processo operacional de planejamento e orçamento que exige de cada administrado a fundamentação da necessidade dos recursos totais solicitados, e em detalhes lhe transfere o ônus da prova, a fim de que ele justifique a despesa" (KOHAMA, Contabilidade..., p. 81). Surgiu nos Estados Unidos, e houve tentativa de implantá-lo, na década de 1970, especialmente durante o Governo de Jimmy Carter.
} 
novo orçamento. É o que se pode denominar de "sistema incrementalista", nas palavras de José Joaquim Teixeira Ribeiro. ${ }^{141}$

\subsubsection{Etapa intermediária}

Com base nos parâmetros e referenciais monetários fixados pela Secretaria de Orçamento Federal do Ministério do Planejamento, Orçamento e Gestão, os órgãos setoriais elaboram suas propostas orçamentárias. Essa elaboração envolve a análise da adequação da estrutura programática do setor e das necessidades de alterações, com a fixação dos referenciais monetários a serem observados pelas unidades orçamentárias.

No âmbito da Justiça Federal, cabe destaque, neste ponto, ao Conselho da Justiça Federal, que é o órgão criado pela Constituição para funcionar junto ao Superior Tribunal de Justiça, com a finalidade de exercer a supervisão administrativa e orçamentária da Justiça Federal de primeiro e segundo graus (CF, art. 105, parágrafo único). Cabe a ele elaborar a proposta orçamentária setorial das unidades orçamentárias que compõem a Justiça Federal.

As unidades orçamentárias, limitadas pelos valores indicados pelo órgão setorial, verificam as propostas das unidades administrativas (onde houver), a adequação da estrutura programática, os gastos dos exercícios anteriores, as prioridades e as necessidades do setor, além de formalizar sua proposta orçamentária.

A proposta da unidade orçamentária é encaminhada ao órgão setorial, que desempenha o papel de articulador em seu âmbito de atuação. Cabe aos órgãos setoriais fixar, atendidas as prioridades de sua área, os referenciais monetários a serem seguidos pelas unidades orçamentárias, bem como coordenar o processo de elaboração de sua proposta. Deve, por conseguinte, avaliar as propostas das unidades orçamentárias em função das necessidades a serem atendidas e consolidá-las, formalizando a proposta orçamentária do órgão setorial. ${ }^{142}$ A proposta orçamentária setorial é, então, encaminhada ao órgão central.

\footnotetext{
${ }^{141}$ Lições de finanças públicas, p. 107.

${ }^{142}$ BRASIL, Ministério do Planejamento, Manual técnico de orçamento, p. 15.
} 
No caso dos Poderes Legislativo e Judiciário, bem como do Ministério Público da união, esses encaminharão suas propostas ao órgão central, por meio do Sistema Integrado de Dados Orçamentários (Sidor), até o dia 10 de agosto (art. 14 da Lei $\mathrm{n}^{\mathrm{o}}$ 10.934/04 - LDO para 2005).

\subsubsection{Etapa final}

Compete à Secretaria de Orçamento Federal consolidar e formalizar a proposta orçamentária da União.

Ela recebe informações da Secretaria de Política Econômica do Ministério da Fazenda sobre meta de inflação, taxa média de juros, taxa média de câmbio, evolução da massa salarial, expectativa de crescimento real do PIB, repassando-as à Secretaria da Receita Federal, que faz as previsões de arrecadação tributária.

Com esses dados, mais as informações relacionadas ao montante de refinanciamento da dívida, resultado primário desejado e outras, a Secretaria de Orçamento Federal passa ao processo decisório, em que são analisadas as propostas setoriais e definidas as dotações, sendo então consolidadas as propostas setoriais e finalizada a proposta orçamentária, a qual é encaminhada à Presidência da República, acompanhada de exposição de motivos do Ministro do Planejamento, Orçamento e Gestão. $^{143}$

O Presidente, concordando com a proposta, remete o projeto de lei para o Congresso Nacional, por meio de Mensagem, até o dia 31 de agosto (CF, art. 84, XXIII; ADCT, art. 35, $\S 2^{\circ}$, III).

\subsubsection{Fase legislativa}

O papel do Poder Legislativo é fundamental em matéria orçamentária, especialmente no sistema adotado pela legislação brasileira. Em nosso processo orçamentário, cabe ao Poder Legislativo aprovar o projeto de lei orçamentária anual

\footnotetext{
${ }^{143}$ BRASIL, Senado Federal, Consultoria de Orçamentos, Fiscalização e Controle, Sistema orçamentário brasileiro, p. 1. Disponível em: www.senado.gov.br/sf/orcamento/ sistema. Acesso em: 21.7.2004.
} 
(bem como os projetos das demais leis orçamentárias), tendo o poder de alterar a proposta enviada pelo Presidente da República. ${ }^{144}$ Além disso, o Poder Legislativo é responsável pela fiscalização financeira e orçamentária de toda a Administração Pública, assunto que será objeto de referência no item 4.6. Cumpre ressaltar que o Poder Executivo sempre teve papel predominante na elaboração e aprovação da lei orçamentária, o que continua ocorrendo até hoje em muitos países. No Brasil, a situação é diferente, pois o Poder Legislativo desempenha papel relevante, principalmente após a Constituição de 1988, decorrente não só dos poderes que tem sobre a aprovação da lei orçamentária, como também da fixação das metas e prioridades na lei de diretrizes orçamentárias e da possibilidade de propor e aprovar emendas ao texto.

O processo de aprovação da lei orçamentária anual federal brasileira inicia sua fase legislativa quando a Mensagem do Presidente da República, encaminhando o projeto de lei orçamentária, é entregue ao Presidente do Senado, que a recebe e convoca sessão conjunta, na qual a Mensagem é lida (Resolução do Congresso Nacional 1, de 1970, art. 89). Em seguida, o projeto é encaminhado à Comissão Mista de Planos, Orçamentos Públicos e Fiscalização (CMO). Cabe à referida Comissão examinar e emitir parecer sobre o projeto de lei orçamentária e os programas previstos, bem como sobre as emendas apresentadas $\left(\mathrm{CF}\right.$, art. $\left.166, \S 1^{\circ}\right)$.

A Comissão Mista, composta por membros de ambas as Casas do Congresso Nacional ${ }^{145}$, analisa o projeto por meio de comissões temáticas, sob o comando de Relatores-setoriais, nas quais são realizadas audiências públicas e é elaborado um relatório setorial.

Esses relatórios, bem como eventuais mensagens modificativas encaminhadas pelo Presidente da República, são direcionados ao Relator-Geral da Comissão Mista, a quem caberá apresentar parecer preliminar ( $\mathrm{RCN} 1$, de 2001, art. 18), podendo incorporar ao projeto eventuais reestimativas de receita ( $\operatorname{RCN~1,~de~2001,~art.~18,~} \S 4^{\circ}$ ).

\footnotetext{
${ }^{144}$ Em alguns sistemas, como o inglês, o Parlamento não pode introduzir modificações, somente aprovar ou rejeitar o projeto como um todo (VILLEGAS, Curso de finanzas, derecho financiero y tributário, p. 802).

${ }^{145}$ A Comissão compõe-se de 84 membros titulares, sendo 63 Deputados e 21 Senadores (RCN 1, de 2001 , art. $\left.3^{\circ}\right)$.
} 
Uma vez encaminhado o projeto de lei orçamentária ao Poder Legislativo, superada a fase de análise pelas comissões temáticas e emitido o parecer preliminar pelo Relator-Geral, as alterações só poderão ocorrer por meio de emendas dos parlamentares e das Comissões Permanentes, observados os requisitos do art. 166, $\S 3^{\circ}$, da $\mathrm{CF}$ e o art. 21 da RCN 1, de 2001.

Iniciada a votação, o Presidente da República não poderá mais propor modificações ao projeto $\left(\mathrm{CF}\right.$, art. $\left.166, \S 5^{\circ}\right)$.

Assim, eventuais modificações em que o Poder Judiciário possa ter interesse, a partir desta fase, somente poderão ser feitas com intervenção de parlamentares, por meio de emendas.

As emendas ao projeto de lei orçamentária somente podem ser aprovadas caso $\left(\mathrm{CF}\right.$, art. $\left.166, \S 3^{\circ}\right)$ :

I - sejam compatíveis com o plano plurianual e com a lei de diretrizes orçamentárias;

II - indiquem os recursos necessários, admitidos apenas os provenientes de anulação de despesa, excluídas as que incidam sobre:

a) dotações para pessoal e seus encargos;

b) serviço da dívida;

c) transferências tributárias constitucionais para Estados, Municípios e Distrito Federal; ou

III - sejam relacionadas:

a) com a correção de erros ou omissões; ou

b) com os dispositivos do texto do projeto de lei 
E, ainda, "não sejam constituídas de várias ações que devam ser objeto de emendas distintas", nem contrariem as normas da RCN 1, de 2001, bem como as aprovadas previamente pela Comissão (RCN 1, de 2001).

Nota-se haver restrições bastante significativas para a apresentação de emendas, dadas as diversas limitações impostas, ficando muito reduzida a capacidade de atuação dos parlamentares.

Analisadas as emendas e emitido o parecer final da Comissão Mista, este deve ser encaminhado ao Congresso Nacional para votação. Em seguida, é feita a sistematização das decisões e é gerado o Autógrafo.

Procede-se ao encaminhamento do documento para o chefe do Poder Executivo (no caso, o Presidente da República, por se tratar da esfera federal), que recebe o projeto e pode sancioná-lo ou vetá-lo (total ou parcialmente).

Se houver veto total ou parcial, o Congresso Nacional delibera sobre a decisão presidencial, podendo rejeitá-la ou não.

Rejeitado o veto, o projeto inicialmente aprovado pelo Poder Legislativo é encaminhado ao Poder Executivo para a promulgação. Mantido o veto, o projeto é promulgado sem a parte vetada. Em seguida, procede-se à publicação.

\subsubsection{A estipulação dos limites orçamentários e a autonomia financeira do Poder}

\section{Judiciário}

O art. 99 da CF estabelece:

Art. 99. Ao Poder Judiciário é assegurada autonomia administrativa e financeira.

$\S 1^{\circ}$ - Os tribunais elaborarão suas propostas orçamentárias dentro dos limites estipulados conjuntamente com os demais Poderes na lei de diretrizes orçamentárias.

$\S 2^{\circ}-\mathrm{O}$ encaminhamento da proposta, ouvidos os outros tribunais interessados, compete: 
I - no âmbito da união, aos Presidentes do Supremo Tribunal Federal e dos Tribunais Superiores, com a aprovação dos respectivos tribunais;

II - no âmbito dos Estados e no do Distrito Federal e Territórios, aos Presidentes dos Tribunais de Justiça, com a aprovação dos respectivos tribunais.

$\S 3^{\circ}-$ Se os órgãos referidos no $\S 2^{\circ}$ não encaminharem as respectivas propostas orçamentárias dentro do prazo estabelecido na lei de diretrizes orçamentárias, o Poder Executivo considerará, para fins de consolidação da proposta orçamentária anual, os valores aprovados na lei orçamentária vigente, ajustados de acordo com os limites estipulados na forma do $\S 1^{\circ}$ deste artigo.

$\S 4^{\circ}-$ Se as propostas orçamentárias de que trata este artigo forem encaminhadas em desacordo com os limites estipulados na forma do $\S 1^{\circ}$, o Poder Executivo procederá aos ajustes necessários para fins de consolidação da proposta orçamentária anual.

$\S 5^{\mathrm{o}}$ - Durante a execução orçamentária do exercício, não poderá haver a realização de despesas ou a assunção de obrigações que extrapolem os limites estabelecidos na lei de diretrizes orçamentárias, exceto se previamente autorizadas, mediante a abertura de créditos suplementares ou especiais.

O limite de despesas do Poder Judiciário, estipulado pela lei de diretrizes orçamentárias, a ser observado por ocasião da elaboração da proposta orçamentária, conforme prevê o art. $99, \S 1^{\circ}$, da $\mathrm{CF}$, faz surgir uma das questões mais relevantes na discussão acerca da autonomia financeira do Poder Judiciário.

O texto constitucional é claro ao dizer que os limites serão estipulados conjuntamente com os demais poderes na lei de diretrizes orçamentárias.

Disso se infere que, por ocasião da elaboração da lei de diretrizes orçamentárias, há necessidade de se observar mecanismos que garantam a participação efetiva do Poder Judiciário no processo que leva à estipulação desses referenciais, sob pena de inconstitucionalidade do dispositivo legal. ${ }^{146}$

\footnotetext{
${ }^{146}$ No Estado de Minas Gerais, existe a Comissão de Compatibilização e Acompanhamento Orçamentário, prevista no art. $155, \S 2^{\circ}$, da CE, e instituída pela Lei Estadual $n^{\circ} 10.572 / 91$, que tem como função receber as propostas dos poderes e estabelecer, em regime de colaboração, a compatibilização delas, fixando ao final os limites de despesas que constarão da LDO. O item 7.2.7 traz mais detalhes sobre o assunto.
} 
O Supremo Tribunal Federal já teve oportunidade de se manifestar sobre o assunto em decisões cautelares:

O Supremo Tribunal Federal, em duas oportunidades (ADIMC 468-9, Rel. Min. Carlos Velloso, e ADIMC 810-2, Rel. Min. Francisco Rezek), deferiu a suspensão cautelar da vigência de disposições legais que fixaram limite percentual de participação do Poder Judiciário no Orçamento do Estado sem a intervenção desse Poder. A hipótese dos autos ajusta-se aos precedentes referidos, tendo em vista que se trata de impugnação dirigida contra a Lei de Diretrizes Orçamentárias do Estado do Paraná para o exercício de 1999, que fixou o limite de 7\% (sete por cento) de participação do Poder Judiciário na receita geral do Estado totalmente à sua revelia. Cautelar deferida. ${ }^{147}$

Uma vez estipulados os limites pela lei de diretrizes orçamentárias, há ainda outras questões relacionadas ao tema que merecem reflexão.

O Poder Judiciário, na esfera federal, tem sua autonomia financeira limitada pelos referenciais monetários exatos fixados na Secretaria de Orçamento Federal, nos termos dos limites da LDO. Esses valores são calculados com base nas informações prestadas pelos diversos órgãos da Administração Pública envolvidos com a arrecadação de recursos e previsão de comportamento dos agentes econômicos, conforme parâmetros estabelecidos pela lei de diretrizes orçamentárias.

A partir desses valores que lhes são informados, os Tribunais elaboram suas propostas orçamentárias, adequando seus gastos aos referidos limites. Desse modo, nesta fase, a autonomia administrativa e financeira do Poder Judiciário restringe-se à organização de alguns programas e à previsão das respectivas dotações, sem que possa reivindicar valores superiores aos estabelecidos, ainda que se mostrem necessários. Cabe ressaltar também que outras limitações são impostas ao exercício da autonomia financeira nesta fase, como as despesas obrigatórias, cuja variação nas dotações é pequena - exemplo dos recursos destinados ao pagamento com pessoal, restando poucos itens sobre os quais o Poder Judiciário tenha condições de pleitear valores maiores. Assim, o que se constata é que a autonomia financeira do Poder Judiciário, na

\footnotetext{
${ }^{147}$ Ac. un. do STF-Pleno, deferindo pedido de medida cautelar, para suspender, com eficácia ex tunc, até a decisão final da ação direta, no art. $8^{\circ}$ da Lei n ${ }^{\circ} 12.214$, de 10.7.1998, do Estado do Paraná, a expressão "Poder Judiciário - 7\%" - ADIn 1.9117/PR, rel. Min. Ilmar Galvão, j. 19.11.1998. Reqte.: ProcuradorGeral da República; Rcdos.: Governador do Estado do Paraná e outra - DJU 12.3.1999, p. 2 - Ementa oficial. RJIOB 1/13447.
} 
fase administrativa de elaboração do orçamento, é mínima. E, na fase subsequente, eventuais acréscimos nas dotações terão de ser pleiteados junto ao Poder Legislativo, com o objetivo de fazer aprovar emendas ao projeto que atendam às necessidades do Poder Judiciário.

Outro aspecto relevante é a inexistência de mecanismos que permitam ao Poder Judiciário aferir a correção dos cálculos elaborados unilateralmente pela Secretaria de Orçamento Federal, não havendo previsão de participação, direta ou por meio de fiscalização, do Poder Judiciário nesse procedimento. É evidente que os complexos cálculos elaborados pela Secretaria de Orçamento Federal, bem como pelos demais setores do Poder Executivo envolvidos no processo, seja para fixar os valores de previsão de arrecadação, seja para estabelecer os referenciais monetários previstos na lei de diretrizes orçamentárias, estão sujeitos a uma série de decisões que podem alterar significativamente o resultado final, sem que o Poder Judiciário nelas interfira, o que está em desacordo com o estabelecido na parte final do $\S 1^{\circ}$ do art. 99 da CF, segundo o qual a fixação dos limites deve ser feita conjuntamente com os demais poderes. Os valores que limitam os gastos do Poder Judiciário estão, dessa forma, sob controle significativo do Poder Executivo, pois, ainda que os limites tenham sido fixados em lei (LDO) aprovada pelo Poder Legislativo, como se nota, seus valores exatos ficam na dependência de atos do Poder Executivo, que transformam os limites em valores monetários exatos. A determinação constitucional, nesta hipótese, não pode se restringir à fase de elaboração e aprovação da lei de diretrizes orçamentárias, uma vez que esta se completa com a atuação do Poder Executivo ao elaborar os cálculos. Assim, é também imprescindível, para a observância fiel do que estabelece a Constituição, a participação do Poder Judiciário neste procedimento, sob pena de eivar de inconstitucionalidade o ato administrativo dele resultante.

\subsubsection{O encaminhamento da proposta orçamentária do Poder Judiciário}

Conforme estabelece o $\S 2^{\circ}$ do art. 99 da CF, anteriormente transcrito, compete aos Tribunais, pelas autoridades mencionadas no referido dispositivo legal, encaminhar as respectivas propostas orçamentárias. 
Alguns questionamentos surgem em relação a quem deva ser encaminhada a proposta: se ao Poder Executivo, para inclusão no projeto final de lei orçamentária, ou se diretamente ao Poder Legislativo, a quem competirá deliberar sobre o documento.

Clèmerson Clève faz referência à questão:

\begin{abstract}
Não se sabe exatamente se deve o Judiciário encaminhar a usa proposta diretamente ao Poder Legislativo (a proposta constituiria uma providência assimilável à iniciativa legislativa) ou se, afinal, deve aquele Poder encaminhar referida proposta ao Executivo, detentor da iniciativa privativa da lei orçamentária (art. 165 da CF). A verdade é que, com o primeiro ou com o segundo encaminhamento deve necessariamente ser considerada a proposta do Judiciário que, incluída no projeto de lei orçamentária (pelo Executivo ou já no âmbito do Legislativo), sujeitar-se-á à aprovação dos parlamentares. ${ }^{148}$
\end{abstract}

$\mathrm{O}$ assunto está previsto na legislação em muitos casos. Na esfera federal, por exemplo, a proposta deve ser encaminhada ao Poder Executivo. O art. 14 da LDO da união para 2005 (Lei $n^{\circ}$ 10.934/04) determina que os Poderes Legislativo e Judiciário, bem como o Ministério Público da união, encaminhem suas propostas ao órgão central, por meio do Sistema Integrado de Dados Orçamentários (Sidor), até o dia 10 de agosto.

O Estado de São Paulo também utiliza esse procedimento:

Dentro dos limites estipulados conjuntamente com os demais Poderes na lei de diretrizes orçamentárias, o Tribunal de Justiça, pelo seu Órgão Especial, elaborará proposta orçamentária do Poder Judiciário, encaminhando-a, por intermédio de seu Presidente, ao Poder Executivo, para inclusão no projeto de lei orçamentária (Constituição Estadual, art. 56).

Isso não ocorre em outros Estados, como no Rio de Janeiro: "O encaminhamento da proposta, depois de aprovada pelo Tribunal de Justiça, será feito pelo seu Presidente, à Assembleia Legislativa (CE, art. 152, § $\left.2^{\circ}\right)$.

Também no Ceará o encaminhamento é feito diretamente ao Poder Legislativo:

O Tribunal de Justiça elaborará proposta orçamentária relativa ao Poder Judiciário, dentro dos limites estipulados na Lei de Diretrizes Orçamentárias, depois de ouvidos os tribunais de segunda instância, os quais apresentarão suas propostas parciais e, sendo aprovada pelo plenário do Tribunal de Justiça, será encaminhada pelo Presidente à Assembleia Legislativa (CE, art. 99, $\left.\S 1^{\circ}\right)$.

${ }^{148}$ Poder Judiciário: autonomia e justiça, p. 36. 
A Constituição prevê a iniciativa privativa da lei orçamentária para o Presidente da República (esfera federal), nos termos do art. 165, III. No entanto, a autonomia financeira, que dá aos tribunais competência para elaboração e encaminhamento da proposta orçamentária (art. $99, \S \S 1^{\circ}$ e $2^{\circ}$ ), torna necessária uma análise sistemática do texto constitucional que compatibilize os mencionados dispositivos, a fim de que se possa concluir qual é o procedimento a ser adotado no encaminhamento da proposta orçamentária do Poder Judiciário.

O STF já tem se manifestado sobre questão diretamente relacionada ao tema em discussão, que traz subsídios importantes para a compreensão e a solução do problema posto.

Trata-se da possibilidade ou não de alteração, pelo Poder Executivo, da proposta elaborada pelos tribunais, quando essa lhe é encaminhada para inclusão no projeto final da lei orçamentária. E decidiu que:

[...] o Poder Executivo não dispõe de competência institucional para introduzir cortes unilaterais na proposta orçamentária que lhe foi encaminhada pelos Tribunais, eis que, nesse tema, o único árbitro da questão é o Poder Legislativo, a quem incumbe, constitucionalmente, a apreciação final do projeto de lei orçamentária. ${ }^{149}$

Tal decisão ajusta-se perfeitamente ao ordenamento jurídico em vigor, deixando claro que cabe ao Poder Legislativo a decisão final sobre as receitas e as despesas em matéria orçamentária. ${ }^{150}$ Esta é a interpretação consoante o texto constitucional, não sendo facultado ao Poder Executivo, por conseguinte, alterar a proposta orçamentária encaminhada pelo Poder Judiciário. Tal ato importa em violação à Constituição, por afronta à autonomia financeira do Poder Judiciário, nos termos do art. $99, \S \S 1^{\circ}$ e $2^{\circ}$.

Já houve manifestação do Supremo Tribunal Federal também em caráter administrativo, consoante se depreende da Ata da 12a Sessão Administrativa, realizada em 2.8.1989, cujo trecho transcrevemos:

\footnotetext{
${ }^{149}$ STF, MS 22.685/AL, rel. Min. Celso de Mello, j. 19.2.2002. No mesmo sentido: MS 23.783-MC/RS, rel. Min. Maurício Corrêa, j. 5.10.2000; MS 24.380/RO, rel. Min. Ellen Gracie, j. 15.10.2002.

${ }^{150}$ A Constituição Federal, no art. 48, II, expressamente atribui competência ao Congresso Nacional para dispor sobre matéria orçamentária.
} 
O Tribunal, interpretando as normas constantes dos arts. 99 e seus parágrafos; 84 , inciso XXIII; 165, inciso III e seus parágrafos $5^{\circ}$, I, e $6^{\circ} ; 166$ e seus parágrafos, bem assim as demais disposições, todas da Constituição Federal de 1988, referentes à autonomia administrativa e financeira do Poder Judiciário, à elaboração de sua proposta orçamentária e à iniciativa do projeto de lei orçamentária, decidiu: a) as propostas orçamentárias dos Tribunais, a que alude o art. $99, \S 2^{\circ}$, I, da Constituição, devem ser elaboradas, dentro dos limites estipulados pela lei de diretrizes orçamentárias, com a aprovação dos respectivos Tribunais; b) o Presidente de cada Tribunal encaminhará a proposta orçamentária respectiva, após aprovada, ao Presidente da República, para ser integrada, nos mesmos termos de sua formulação, ao projeto de lei orçamentária, que o Chefe do Poder Executivo enviará ao Congresso Nacional (Constituição, arts. 165, III; 166, $\S 6^{\circ}$ e 84, XXIII). Decisão unânime (grifo nosso).

O Poder Executivo somente pode efetuar cortes na proposta encaminhada pelo Poder Judiciário na hipótese do $\S 4^{\circ}$ do art. 99 da CF, isto é, caso essa seja apresentada em desacordo com os limites estipulados na lei de diretrizes orçamentárias.

Ainda que a lei de diretrizes orçamentárias não estipule o limite das despesas do Poder Judiciário, como tem ocorrido no Estado de São Paulo ${ }^{151}$ e em outras unidades da Federação, cabe ao Poder Executivo encaminhar a proposta, sem alterações, para o Poder Legislativo, e este se encarregará de elaborar a lei orçamentária, na qual poderá ou não acolher a proposta, mantendo ou não os valores nela contidos. ${ }^{152}$

Em virtude do exposto, torna-se pouco relevante determinar se $\mathrm{o}$ encaminhamento da proposta orçamentária deve ser feito ao Poder Executivo, para inclusão no projeto final de lei orçamentária a ser encaminhado ao Poder Legislativo, ou diretamente ao Poder Legislativo. Isso porque, na primeira hipótese, não há dúvidas de que a proposta encaminhada pelo Poder Judiciário deverá ser integralmente incorporada ao projeto de lei orçamentária, sem qualquer alteração. Assim, se observado esse procedimento, o Poder Executivo, uma vez receptor da proposta do Poder Judiciário, seria mero intermediário na burocracia de seu encaminhamento, cujo destino é o Poder Legislativo.

\footnotetext{
${ }^{151}$ A Lei Estadual no 11.782/04 (LDO para 2005) não faz referência a esses limites.

${ }^{152}$ Nos EUA, a proposta encaminhada pelo Poder Judiciário também não pode sofrer alterações por parte do Executivo: "The proposal is first reviewed by the Judicial Conference's Budget Committee, then approved by the Judicial Conference and submitted directly to the Congress with detailed justifications. By law, the President must include in his budget to Congress the judiciary's budget proposal without change" (USA, The federal court..., p. 41).
} 
Os argumentos expostos mostram ser mais adequada ao ordenamento jurídico, interpretando-o sistematicamente, a tese de que a proposta orçamentária do Poder Judiciário deve ser encaminhada diretamente ao Poder Legislativo.

\subsubsection{O Poder Judiciário e a iniciativa legislativa em matéria orçamentária}

A Constituição é clara no sentido de atribuir ao Poder Judiciário a iniciativa legislativa no que se refere à elaboração de sua proposta orçamentária, em face do disposto no art. $99, \S 1^{\circ}$, como já foi visto anteriormente.

O mesmo não se pode dizer com relação à iniciativa legislativa nas demais questões de natureza orçamentária, como os créditos adicionais e a criação de fundos, tornando necessário um esforço de interpretação para que se possa extrair a conclusão correta.

O art. 61 da Constituição Federal, ao tratar da iniciativa legislativa, atribui exclusividade ao Presidente da República para a iniciativa de leis em vários temas, e neles não há expressa previsão para matéria financeira ou orçamentária.

Há apenas menção, no art. $61, \S 1^{\circ}$, II, $b$, à “organização administrativa e judiciária, matéria tributária e orçamentária, serviços públicos e pessoal da administração dos Territórios". No entanto, vê-se claramente que, nessa hipótese, a referência diz respeito ao caso específico dos Territórios, ou seja, há iniciativa privativa do Presidente da República em matéria orçamentária dos Territórios, não abrangendo os outros entes da Federação.

No entanto, o fato de haver iniciativa privativa do Poder Executivo para as leis orçamentárias (plano plurianual, lei de diretrizes orçamentárias e orçamentos anuais), nos termos do que dispõe o art. 165 da Constituição, tem dado margem à que o Poder Executivo considere também ser sua a iniciativa de leis que tratam das demais questões orçamentárias. $^{153}$

\footnotetext{
${ }^{153}$ Essa posição é demonstrada com clareza nas razões de veto total ao projeto de Lei no 108 , de 2006, do Estado de São Paulo, expostas na mensagem n ${ }^{0}$ 84, de 4 de maio de 2006, encaminhadas pelo Governador de Estado (Cláudio Lembo) à Assembleia Legislativa (publicado no Diário Oficial do Estado de São
} 
Nesse ponto, é interessante proceder a uma interpretação histórica, trazendo à colação a redação que constava da Constituição anterior, de 1967, nos seguintes termos:

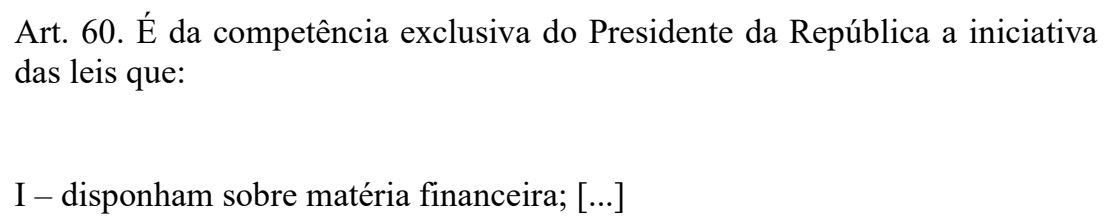

Manteve-se a redação após a alteração do texto constitucional promovida pela Emenda 1/1969, mudando apenas o número do artigo, que passou a ser o 57.

A redação da Constituição anteriormente vigente era clara no sentido de atribuir exclusividade ao Presidente da República para iniciar o processo legislativo em todas as leis que tratem de matéria financeira.

Considerando que esse dispositivo não foi mantido, isso permite concluir não estar em vigor a iniciativa legislativa privativa do Presidente da República em todas as questões orçamentárias, mas apenas naquelas expressamente enumeradas pela Constituição, quais sejam: plano plurianual, lei de diretrizes orçamentárias e lei orçamentária anual.

Há que se levar em consideração ainda que, no ordenamento jurídico nacional, o Poder Judiciário tem iniciativa legislativa para a elaboração de sua proposta orçamentária $\left(\mathrm{CF}\right.$, art. $\left.99, \S 1^{\circ}\right)$. Seria pouco razoável aceitar a tese de que, tendo o Poder Judiciário iniciativa para elaborar sua proposta orçamentária, não tenha iniciativa para solicitar eventuais alterações que se façam necessárias após a aprovação do orçamento, mediante a abertura de créditos adicionais.

E, consoante a lição de Clèmerson Clève, o "princípio organizativo da inicialidade legislativa", que compreende a iniciativa reservada de algumas leis, integra o conceito de autonomia institucional, fundamental para assegurar a independência do Poder Judiciário. ${ }^{154}$

Paulo Poder Legislativo, em 5 de maio de 2006, p. 12).

${ }^{154}$ Poder Judiciário: autonomia e justiça, p. 35. 
Sendo assim, a única interpretação que se mostra coerente com o sistema jurídico, analisando-o por meio de interpretação histórica ou sistemática, é a de que o Poder Judiciário tem iniciativa legislativa para projetos de lei relativos a créditos adicionais nas questões de seu interesse institucional.

Não somente nos créditos adicionais, mas também em toda e qualquer matéria financeira que seja diretamente relacionada a seus interesses, como a criação de fundos ou alteração da legislação a eles referente, por exemplo. Os Tribunais têm iniciativa legislativa em questões como a criação de varas judiciárias $(\mathrm{CF}$, art. 96, I, d), a organização de suas secretarias $(\mathrm{CF}$, art. $96, \mathrm{I}, \mathrm{b})$ e outros, não havendo razão para que não sejam dotados de iniciativa legislativa para dispor sobre os fundos especiais orçamentários que estejam sob sua administração.

Não é aceitável, em face do princípio da separação de poderes e da autonomia financeira que a Constituição atribui ao Poder Judiciário, que este Poder tenha de solicitar ao Poder Executivo que dê início ao processo legislativo em projetos de seu interesse, o que acabaria por conferir ao Executivo a faculdade de não atender a solicitação, em clara afronta ao princípio da separação de poderes.

Somente o Poder Legislativo é que pode deliberar sobre o projeto encaminhado pelo Poder Judiciário, atendendo ou não a solicitação, sem que o Poder Executivo nele tenha qualquer interferência.

\subsection{A execução do orçamento}

A execução do orçamento é uma tarefa atribuída ao Poder Executivo, independentemente do sistema ou regime de governo adotado. Há variações nas diversas estruturas administrativas dos vários sistemas orçamentários com relação à influência do Poder Legislativo neste processo, notando-se que, em alguns países, há maior intervenção e, em outros, a participação é menos intensa.

O papel do processo de execução do orçamento é cumprir, com a maior fidelidade possível, o orçamento aprovado, de modo que se façam apenas os ajustes necessários, no montante imprescindível para adequar a aplicação das receitas 
arrecadadas no atendimento às necessidades públicas, sempre tendo em vista o interesse da coletividade.

O processo de execução do orçamento é orientado pelo princípio da flexibilidade, por meio do qual se busca cumprir o estabelecido pela lei orçamentária em seu aspecto essencial, para o que se fazem necessários ajustes nas previsões e programações orçamentárias durante o curso de sua execução, uma vez que "nem sempre as previsões podem captar todas as condições vigentes à época da execução, e não é possível programar de forma que a execução se ajuste completamente a previsões". ${ }^{155}$

Há de se compatibilizar, dessa forma, a necessidade de se cumprir fielmente o orçamento, do modo como aprovado pelo Poder Legislativo, com as imprescindíveis alterações que se fazem necessárias ao longo do exercício financeiro, sem, com isso, descaracterizá-lo e fazer dele uma peça de ficção.

Far-se-á, neste item, uma síntese dos procedimentos de execução orçamentária e financeira do governo federal brasileiro, voltando-se, basicamente, para o aspecto da despesa pública, com destaque para os pontos de interesse do Poder Judiciário, mostrando-se os mecanismos utilizados pela legislação brasileira para dar cumprimento aos objetivos e ao princípio do orçamento público.

A lei orçamentária anual (que passaremos a designar Lei Orçamentária), regularmente aprovada no final de um exercício financeiro, produz seus efeitos a partir do exercício financeiro seguinte, no qual se aplicarão as disposições nela contidas, com a arrecadação das receitas previstas e a realização dos gastos nela autorizados.

Uma vez aprovada e promulgada a Lei Orçamentária, e iniciado o exercício financeiro, começa a ser executado o orçamento. A execução do orçamento ocorre no período de sua vigência, que se inicia no dia $1^{\circ}$ de janeiro e termina em 31 de dezembro, coincidindo com o ano civil, nos termos do art. 34 da Lei $n^{\circ} 4.320 / 64 .^{156}$

\footnotetext{
${ }^{155}$ SILVA, José Afonso da. Orçamento-programa ..., p. 310.

${ }^{156}$ Existem muitas variações nesse aspecto em relação aos demais países, cada um fixando o exercício financeiro da forma que entende mais conveniente. Há desde casos em que o exercício financeiro corresponde a um ano, mas não necessariamente iniciando-se no dia $1^{\circ}$ de janeiro, até casos em que o exercício
} 
Cabe ao Poder Executivo ${ }^{157}$, em até 30 dias após a publicação da lei orçamentária, estabelecer a programação financeira e o cronograma de execução mensal de desembolso (Lei de Responsabilidade Fiscal, art. $8^{\circ}$ ).

Neste ponto, cumpre lembrar que o orçamento, quando aprovado, corresponde a uma previsão de receitas e autorização de despesas. As receitas previstas no orçamento, no entanto, não estão disponíveis por ocasião do início do exercício financeiro, mas ingressarão nos cofres públicos durante seu curso. Assim, as despesas terão de ser efetuadas na medida da disponibilidade dos recursos existentes, e não de acordo com a vontade do administrador, ainda que estejam previstas no orçamento.

Disso decorre a necessidade de uma programação financeira e o cronograma de desembolso.

O Decreto-Lei $\mathrm{n}^{\mathrm{o}} 200 / 67^{158}$, que estabeleceu o planejamento da ação governamental, incluiu como um de seus instrumentos a programação financeira, a fim de ajustar o ritmo de execução do orçamento ao fluxo de ingressos, de modo a assegurar a liberação dos recursos necessários à execução dos programas (arts. $7^{\circ}$ e 17).

Por meio da programação financeira, faz-se um quadro de cotas que cada unidade orçamentária poderá gastar mensalmente, mediante cálculo que leva em consideração vários fatores, como o fluxo previsto para o ingresso de recursos, as despesas ordinárias da unidade considerada, as variações decorrentes do cronograma de obras e todos os demais fatores que possam influenciar na necessidade de efetivação das despesas. Consegue-se, dessa forma, assegurar às unidades orçamentárias os recursos necessários e suficientes para melhor executar os programas e manter o equilíbrio entre a receita arrecadada e a despesa realizada, reduzindo-se as insuficiências de caixa, conforme previsto no art. 48 da Lei $n^{\circ}$ 4.320/64. Esse sistema mostra-se mais eficiente

financeiro tem duração superior a um ano. Mesmo no Brasil, essa regra alterou-se várias vezes, como se pode observar na descrição de GIACOMONI (Orçamento público, p. 292-3).

${ }^{157} \mathrm{O}$ órgão central responsável pela programação financeira é a Coordenação-Geral de Programação Financeira (COFIN), da Secretaria do Tesouro Nacional (STN), que integra o Ministério da Fazenda. Disponível em: www.stn.fazenda.gov.br/siafi/atri- buicoes.asp, p. 2. Acesso em: 11.9.2004.

${ }^{158}$ Dispõe sobre a organização da Administração Federal, estabelece diretrizes para a Reforma Administrativa e dá outras providências. 
que o mecanismo de duodécimos ${ }^{159}$, em que as cotas são estabelecidas pela divisão da previsão anual em doze partes iguais, para cada um dos meses do ano, o que evidentemente não corresponde sempre à realidade, dada a oscilação no ingresso de recursos, bem como as variações nas necessidades de despesa, que podem ser diferentes no transcorrer do exercício financeiro.

O cronograma de desembolso é "um instrumento de controle de Tesouraria ou de Caixa, em que se preveem as receitas e os pagamentos das obrigações, que vão sendo assumidas à medida que o orçamento vai sendo executado". 160

A execução da despesa pública requer prévia autorização legal, por meio da Lei Orçamentária ou abertura de crédito adicional, a autorização do ordenador de despesa ${ }^{161}$, bem como a observância das exigências legais de procedimento licitatório. Uma vez superadas essas etapas, e estando a despesa prevista regularmente autorizada pelos procedimentos mencionados anteriormente, passa-se à fase de realização propriamente dita do ato de despesa pública.

Faz-se o empenho ${ }^{162}$ e emite-se a nota de empenho (Lei $n^{\circ} 4.320 / 64$, art. 61). Procede-se à liquidação da despesa ${ }^{163}$, exarando-se a ordem de pagamento (art. 64). Então é feita a entrega da quantia correspondente ao credor (art. 65).

O processo de execução orçamentária é dotado de mecanismos que permitem a adaptação da Lei Orçamentária às alterações surgidas ao longo do exercício financeiro, mantendo os objetivos e os programas fixados pelo Poder Público, em consonância com o princípio da flexibilidade.

\footnotetext{
159 Ainda utilizado em alguns casos, como nos recursos entregues aos Poderes Legislativo e Judiciário, ao Ministério Público e à Defensoria Pública, nos termos do art. 168 da CF, com a redação que lhe foi dada pela EC $45 / 04$.

${ }^{160}$ MACHADO JÚNIOR; REIS, A Lei $4.320 \ldots$, p. 120.

${ }^{161}$ Ordenador de despesa é "toda e qualquer autoridade de cujos atos resultarem emissão de empenho, autorização de pagamento, suprimento ou dispêndio de recursos da união ou pela qual esta responda" (Decreto-Lei $\mathrm{n}^{\mathrm{o}}$ 200/67, art. 80, $\S 1^{\circ}$ ).

${ }^{162}$ Empenho da despesa é "o ato emanado de autoridade competente que cria para o Estado obrigação de pagamento pendente ou não de implemento de condição" (Lei n ${ }^{\circ} 4.320 / 64$, art. 58).

${ }^{163}$ A liquidação consiste na verificação do direito adquirido pelo credor pela análise dos documentos que comprovem a origem e o objeto do que se deve pagar, a importância a pagar e a quem se deve pagar (Lei $\mathrm{n}^{\circ} 4.320 / 64$, art. 63 ).
} 
O principal mecanismo é o dos créditos adicionais. Os créditos adicionais são “autorizações de despesa não computadas ou insuficientemente dotadas na Lei de Orçamento" (Lei 4.320/64, art. 40). Esses créditos podem ser suplementares, especiais ou extraordinários. Os créditos suplementares são os destinados a reforço da dotação orçamentária, utilizados quando há a previsão de um crédito orçamentário, mas os valores consignados mostram-se insuficientes. Os créditos especiais são os destinados às despesas para as quais não exista dotação orçamentária específica (Lei nº 4.320/64, art. 41). Ambos devem ser autorizados por lei (Lei $n^{\circ} 4.320 / 64$, art. 43) e dependem da existência de recursos disponíveis (CF, art. 167, v; Lei n 4.320/64, art. 43). Os créditos extraordinários são aqueles "destinados a despesas urgentes e imprevistas, em caso de guerra, comoção intestina ou calamidade pública" (Lei no 4.320/64, art. 41, III), devendo ser abertos por medida provisória (CF, art. 167, § $\left.3^{\circ}\right)$.

Outro mecanismo é o do contingenciamento. A execução orçamentária, para que ocorra da forma como consta na programação financeira, depende da correspondência entre a receita que está sendo arrecadada efetivamente e aquela que havia sido prevista. Isso nem sempre é possível, tendo em vista os inúmeros fatores e agentes envolvidos no processo econômico. Para evitar desajustes de caixa, o art. $9^{\circ}$ da LRF previu a possibilidade de limitação de empenho.

Uma vez constatado, ao final de um bimestre, que a realização da receita poderá não comportar o cumprimento das metas de resultado primário ou nominal estabelecidas no Anexo de Metas Fiscais, os Poderes e o Ministério Público promoverão, por ato próprio e nos montantes necessários, nos 30 (trinta) dias subsequentes, limitação de empenho e movimentação financeira, segundo os critérios fixados na lei de diretrizes orçamentárias.

Assim, ainda que prevista a dotação na Lei Orçamentária, e incluído o valor na programação financeira, a realização da despesa poderá não ser autorizada, tendo em vista limitação de empenho decorrente de insuficiência na arrecadação de receitas ou cumprimento das metas estabelecidas. ${ }^{164}$

\footnotetext{
${ }^{164}$ Esta questão será analisada em mais detalhes no item 4.5.1, tendo em vista as peculiaridades que envolvem o Poder Judiciário.
} 
As necessidades de adaptação do orçamento durante sua execução também deram origem ao instituto da reserva de contingência, a qual consiste em uma "dotação global não especificamente destinada a determinado órgão, unidade orçamentária, programa ou categoria econômica, cujos recursos serão utilizados para a abertura de créditos adicionais" (Decreto-Lei no 200/67, art. 91). A lei orçamentária anual deve prever reserva de contingência destinada ao atendimento de passivos contingentes e outros riscos e eventos fiscais imprevistos (LRF, art. $5^{\circ}$, III). A forma de utilização dos recursos da reserva de contingência e o estabelecimento de seu montante, definido com base na receita corrente líquida, são estabelecidos na lei de diretrizes orçamentárias (LRF, art. $5^{\circ}$, III). ${ }^{165}$ Com a reserva de contingência, torna-se mais fácil atender a necessidades imprevistas, evitando que se tenha de anular dotações específicas já existentes.

Normalmente, atribui-se ao Poder Executivo autorização para abrir créditos suplementares utilizando-se os recursos consignados na dotação a título de reserva de contingência, como se pode observar no art. $7^{\circ}$, II, da Lei Orçamentária do Estado de São Paulo para o exercício de 2005 (Lei Estadual no 11.816/04), evidenciando um privilégio do Poder Executivo em relação aos demais poderes, pois pode usar os referidos recursos sem necessidade de autorização específica do Poder Legislativo, uma vez que essa autorização já foi prévia e antecipadamente concedida na Lei Orçamentária.

A rapidez e a agilidade exigidas nas alterações durante a execução orçamentária fizeram surgir o que vem sendo denominado margem de remanejamento. As leis orçamentárias, utilizando-se da faculdade prevista no art. $7^{\circ}$, I, da Lei $n^{\circ} 4.320 / 64^{166}$, costumam autorizar o Poder Executivo a abrir créditos suplementares até certo limite, não havendo, pois, nesses casos, necessidade de outra lei para a realização do ato. Os arts. $4^{\circ}$ e $5^{\circ}$ da lei orçamentária da união para 2004 (Lei $n^{\circ} 10.837$, de 16.1.2004) fixam as condições e os limites para a abertura dos referidos créditos suplementares. $\mathrm{O}$ art. $7^{\circ}$,

\footnotetext{
${ }^{165}$ A lei de diretrizes orçamentárias da união para 2005 (Lei n ${ }^{\circ}$ 10.934/04), em seu art. 13, prevê que "a reserva de contingência será constituída, exclusivamente, de recursos do orçamento fiscal, equivalendo, no projeto de lei orçamentária, a, no mínimo, $2 \%$ (dois por cento) da receita corrente líquida e a $1 \%$ (um por cento) na lei, sendo pelo menos metade da reserva, no projeto, considerada como despesa primária para efeito de apuração do resultado final".

166 “A Lei de Orçamento poderá conter autorização ao Executivo para abrir créditos suplementares até
} 
I, da lei orçamentária do Estado de São Paulo para 2005 (Lei Estadual $n^{\circ}$ 11.816/04) autoriza o Poder Executivo a "abrir, durante o exercício, créditos suplementares até o limite de $17 \%$ (dezessete por cento) do total da despesa fixada no art. $2^{\circ}$, observado o disposto no art. 43, da Lei Federal n 4.320, de 17 de março de 1964". Essas autorizações da lei orçamentária permitem maior dinamismo e flexibilidade para modificações nas dotações, facilitando a adaptação do orçamento às alterações ocorridas ao longo do exercício. Devem, no entanto, ser concedidas com moderação, fixando-se limites baixos e rígidos, para evitar-se que o Poder Executivo passe a ter domínio total na execução do orçamento, alterando-o de maneira a desfigurar a Lei Orçamentária aprovada pelo Poder Legislativo, tornando-a verdadeira peça de ficção.

A Constituição, ao exigir autorização legislativa para a abertura de crédito suplementar ou especial (art. 167, V), bem como ao proibir a concessão ou utilização de créditos ilimitados (art. 167, VII), deixou clara a intenção de submeter tais atos à autorização prévia do Poder Legislativo. Uma autorização ampla e genérica concedida ao Poder Executivo na lei orçamentária para a realização de tais atos viola os dispositivos constitucionais citados, sendo, pois, inconstitucional.

Também é possível realizar ajustes no orçamento por meio da transposição, remanejamento ou transferência de recursos de uma categoria de programação para outra ou de um órgão para outro. Esse tipo de alteração no orçamento depende de autorização legal prévia, como expressamente determina o art. 167, VI, da CF. A lei orçamentária do Estado de São Paulo para 2005 já prevê essa autorização em seu art. $8^{\circ}$, dando ao Poder Executivo poderes para remanejar recursos, no âmbito de cada órgão, entre elementos do mesmo grupo de despesa e entre atividades e projetos de um mesmo programa. O mesmo raciocínio exposto anteriormente deve ser aplicado, haja vista que eventuais excessos podem importar em inconstitucionalidade, uma vez que torna inócua a proibição constitucional. Atribuir apenas ao Poder Executivo essa possibilidade também configura privilégio que o coloca em posição de superioridade em relação aos demais poderes, em especial ao Poder Judiciário, que perde agilidade na execução de seu orçamento, uma vez que passa a depender de decisões do Poder Executivo ou do Poder Legislativo para efetuar transposições, remanejamentos e transferências. 


\subsubsection{A limitação de empenho pelo Poder Executivo e a autonomia financeira do}

\section{Poder Judiciário}

Conforme mencionado anteriormente, a execução orçamentária e financeira inicia-se com a publicação da Lei Orçamentária, e, em trinta dias, o Poder Judiciário deve elaborar e publicar por ato próprio o cronograma anual de desembolso mensal, segundo estabelece a Lei de Responsabilidade Fiscal (art. $8^{\circ}$ ) e as leis de diretrizes orçamentárias (LDO da união para 2005, art. 71; LDO da união para 2006, art. 75).

Esse cronograma anual de desembolso mensal terá como referencial o sistema de duodécimos, excetuando-se as despesas com pessoal e encargos sociais, precatórios e sentenças judiciais (LDO da união para 2005, art. 71, $\S 2^{\circ}$ ), e deve ter em vista o cumprimento da meta de resultado primário estabelecida na lei de diretrizes orçamentárias (LDO da união para 2005, art. 16 e Anexo IV - Anexo de Metas Fiscais).

No entanto, pode ocorrer frustração na expectativa de arrecadação, de modo a não permitir que a realização da receita comporte o cumprimento dessas metas, tornando necessários ajustes nas despesas.

Verificada essa circunstância ao final de um bimestre, caberá ao Poder Judiciário, nos termos do art. $9^{\circ}$ da LRF, promover, por ato próprio, nos trinta dias subsequentes, limitação de empenho e movimentação financeira, segundo os critérios fixados na lei de diretrizes orçamentárias. ${ }^{167}$

Essa questão deverá ser objeto de regulação pela lei complementar a que se refere o art. 165, $\S 9^{\circ}$, da $\mathrm{CF}$. No entanto, enquanto não editada a norma, as leis de diretrizes orçamentárias vêm estabelecendo os parâmetros e os procedimentos a serem observados.

Para exemplificar, a LDO da União para 2005 determina que, ocorrendo esta situação, o Poder Executivo informará ao Poder Judiciário, até o vigésimo terceiro dia do mês subsequente ao final do bimestre, o montante que lhe caberá na limitação do

\footnotetext{
${ }^{167}$ A LDO da União para 2005 prevê que o montante da limitação seja estabelecido de forma proporcional à participação de cada um dos Poderes (Legislativo, Judiciário e Executivo) na base contingenciável total $\left(\operatorname{art.} 72, \S 1^{\circ}\right)$.
} 
empenho e da movimentação financeira, especificando os parâmetros adotados e as estimativas de receitas e de despesas (art. 72, § $4^{\circ}$ ). O Poder Judiciário, com base nas informações recebidas, publicará ato em sete dias, estabelecendo os montantes disponíveis para empenho e movimentação financeira $\left(\operatorname{art.} 72, \S 5^{\circ}\right)$.

A Lei de Responsabilidade Fiscal foi publicada com a previsão de que, caso o Poder Judiciário não promova a limitação de empenho nos trinta dias previstos (art. $9^{\circ}$, caput), o Poder Executivo fica autorizado a limitar os valores financeiros segundo os critérios fixados na lei de diretrizes orçamentárias (art. $\left.9^{\circ}, \S 3^{\circ}\right)$.

$\mathrm{O} \S 3^{\circ}$ do art. $9^{\circ}$ foi impugnado pela ADIn 2.238-5, tendo o STF apreciado e deferido, por unanimidade, a medida cautelar para suspender sua eficácia, situação que perdura até hoje, pois ainda não foi decidido o mérito da demanda. Os autores da ação ${ }^{168}$ argumentam que este dispositivo contraria o princípio da separação de poderes, cláusula pétrea da Constituição, pois transforma o Poder Executivo em um "Superpoder" que pode intervir nos demais Poderes, suprindo administrativamente o que os outros deixarem de realizar voluntariamente. ${ }^{169}$

Essa é uma questão que merece ser refletida. Admitindo-se o fato de que o ingresso de receitas nem sempre corresponde ao que foi previsto no orçamento, podendo, em razão das circunstâncias econômicas, haver frustração na arrecadação prevista, torna-se necessária a redução das despesas, a fim de compatibilizar com as receitas, ou buscar outras fontes de recursos, como por meio do crédito público. Considerando que nem sempre é possível recorrer ao crédito público para obter os recursos necessários, quer por razões decorrentes das limitações impostas ao uso deste instrumento de política financeira, quer por outra razão, é razoável admitir-se a redução nas despesas como um mecanismo adequado para manter o equilíbrio orçamentário.

No entanto, em face da autonomia financeira do Poder Judiciário, claramente estabelecida no art. 99 da CF, não é aceitável atribuir competência ao Poder Executivo para efetivar a redução das suas despesas. No Brasil, cabe à lei de diretrizes

\footnotetext{
${ }^{168}$ Partido Comunista do Brasil (PC do B), Partido Socialista Brasileiro (PSB) e Partido dos Trabalhadores (PT).

169 Petição inicial da ADIn 2.238-5, item VIII, § 3º , p. 24.
} 
orçamentárias estabelecer os critérios a serem seguidos quando for necessária a redução das despesas decorrentes da arrecadação inferior à prevista ou for impossível cumprir as metas fixadas (LRF, art. $9^{\circ}$, caput). Transferiu-se, pois, boa parte da responsabilidade pelos cortes de despesas ao Poder Legislativo, conferindo maior legitimidade à decisão a ser tomada.

Ainda assim, a medida não se mostra de todo adequada. Mesmo que os critérios para a limitação do empenho sejam fixados pelo Poder Legislativo na lei de diretrizes orçamentárias, não há garantias de que esses critérios sejam rígidos e precisos, permitindo que o Poder Executivo tenha um grau de discricionariedade excessivamente elevado ao apurar o montante da limitação e, por conseguinte, faça prevalecer seus interesses em detrimento aos do Poder Judiciário.

O art. $9^{\circ}, \S 3^{\circ}$, da LRF, ao autorizar o Poder Executivo a limitar os valores financeiros de empenho de despesas do Poder Judiciário - ainda que nos limites da lei de diretrizes orçamentárias e caso verificados os fatos mencionados no caput do referido dispositivo legal -, efetivamente dispôs contra o princípio da separação de poderes, como já reconheceu o STF, em decisão unânime, ainda que em caráter provisório, ao deferir a medida cautelar requerida na ADIn 2.238-5, à qual já se fez referência anteriormente. Não haverá independência e harmonia dos poderes, tal como determinado pelo art. $2^{\circ}$ da $\mathrm{CF}$, caso o Poder Executivo possa reduzir o montante já previsto na lei orçamentária para as despesas do Poder Judiciário. A autonomia financeira do Poder Judiciário, prevista no art. 99 da CF, interpretada conforme o princípio da separação de poderes, exige não só a participação desse Poder na elaboração de sua proposta orçamentária, mas também o cumprimento fiel do orçamento aprovado no que se refere às dotações do Poder Judiciário. É evidentemente inócuo participar na elaboração de um orçamento que posteriormente não se cumpre, em face dos diversos mecanismos que permitem sua alteração. Portanto, todo e qualquer mecanismo que permita a alteração da proposta orçamentária, no que tange ao Poder Judiciário, não é compatível com o ordenamento jurídico vigente. Ou, para que o seja, deve ser interpretado restritivamente. 
No art. $9^{\circ}, \S 2^{\circ}$, da LRF, há restrições às situações que podem ser objeto de limitação de empenho. Não poderão ser objeto de limitação de empenho as despesas que constituam obrigações constitucionais e legais do ente, inclusive aquelas destinadas ao pagamento do serviço da dívida e as ressalvadas pela lei de diretrizes orçamentárias. Assim, vê-se que, mesmo que haja frustração na realização das receitas, há determinadas despesas que não poderão ser objeto de limitação de empenho. Apenas para exemplificar, não ficam sujeitas à limitação de empenho, em âmbito federal, no exercício financeiro de 2005, além das despesas destinadas ao pagamento do serviço da dívida, despesas com subvenção aos produtores de borracha, subvenção para aquisição de veículos movidos a álcool, apoio ao transporte escolar, fundo partidário, ações de combate à fome, desenvolvimento do Estado do Tocantins e outros 54 itens (LDO da União para 2005, art. 74 e Anexo V).

Na hipótese ora em análise, evidencia-se que a limitação de empenho não é uma regra absoluta, a ser aplicada em todos os casos em que for constatado que a realização de receita poderá não comportar o cumprimento das metas de resultado primário ou nominal. Há inúmeras exceções, previstas na LRF, nas leis de diretrizes orçamentárias e na legislação ordinária. Essas exceções, conforme se pode constatar dos exemplos citados, existem por razões diversas, decorrentes de escolhas políticas muitas vezes efêmeras, que se mostram vinculadas às ações de governo para aquele exercício financeiro, para períodos por vezes mais extensos, ou ainda para projetos específicos.

A autonomia financeira do Poder Judiciário e a independência e separação dos poderes da República é uma decisão permanente da sociedade brasileira. A separação dos poderes é um dos princípios mais importantes da Constituição brasileira, erigido à condição de cláusula pétrea, conforme estabelece o art. $60, \S 4^{\circ}$, III, estando a autonomia financeira do Poder Judiciário, corolário desse princípio, também consagrada em seu art. 99.

Não é aceitável que se possam considerar insuscetíveis de limitação de empenho por parte do Poder Executivo as diversas despesas a que se refere o art. $9^{\circ}, \S 2^{\circ}$, da LRF e, ao mesmo tempo, permitir que essa limitação efetue-se em relação às despesas do Poder Judiciário, protegidas pela autonomia financeira e pelo princípio da separação dos poderes. 
Do exposto, é forçoso concluir que, no sistema constitucional vigente, não é possível haver limitação de empenho de despesas do Poder Judiciário.

\subsubsection{A abertura de créditos adicionais para o Poder Judiciário}

Das três espécies de créditos adicionais (suplementares, especiais e extraordinários), aos quais já se fez referência anteriormente, a que mais interessa ao Poder Judiciário é a dos suplementares. As possibilidades do Poder Judiciário precisar de créditos extraordinários são bastante remotas, bem como de créditos especiais, uma vez que o orçamento prevê os programas vinculados ao Poder Judiciário, sendo raras as situações em que não exista dotação específica para atender às despesas de seu interesse.

No entanto, o uso de créditos suplementares tem se mostrado frequente, em razão da necessidade crescente de recursos para atender às despesas cuja dotação não se mostra suficiente no decorrer do exercício financeiro.

Se houver necessidade de crédito suplementar, é preciso autorização legal para obter o reforço na dotação orçamentária (Lei no 4.320/64, art. 42), bem como é preciso que existam recursos disponíveis, decorrentes de superávit financeiro, excesso de arrecadação, anulação de outras dotações ou produto de operações de crédito (art. 43).

Como o Poder Executivo assume o comando da execução orçamentária, normalmente os pedidos de abertura de créditos suplementares são encaminhados ao órgão competente desse Poder, para então serem submetidos à apreciação do Poder Legislativo. Atualmente, essas solicitações operacionalizam-se por meio dos sistemas eletrônicos de administração financeira e orçamentária.

A LDO da União para 2005 prevê, em seu art. $65, \S 10^{\circ}$, que os projetos de lei relativos a créditos adicionais solicitados pelos órgãos do Poder Judiciário serão encaminhados ao Congresso Nacional em até trinta dias a contar da data do pedido. É de se admitir que, nesta hipótese, não haja interferência do Poder Executivo no projeto, pois tal atitude importaria em violação aos preceitos constitucionais da separação dos poderes e da autonomia financeira do Poder Judiciário. 
No entanto, na maior parte das vezes é o próprio Poder Executivo quem decide sobre a abertura ou não de créditos suplementares, haja vista a existência de autorização prévia na lei orçamentária para a abertura dos referidos créditos, nos termos do art. $7^{\circ}, \mathrm{I}$, da Lei $n^{\circ} 4.320 / 64$, faculdade usualmente denominada "margem de remanejamento".

No Estado de São Paulo, a regulamentação específica sobre esse procedimento já prevê que as solicitações de abertura de créditos suplementares devem ser encaminhadas por meio eletrônico à Secretaria de Economia e Planejamento (Decreto $\mathrm{n}^{\mathrm{o}}$ 48.444/04, arts. 23 a 31), que se manifestará sobre o pedido, encaminhando-o ao Governador (art. 32, II). Considerando que compete ao Poder Legislativo deliberar sobre matéria orçamentária, não é razoável admitir que, na hipótese de despesas do Poder Judiciário, o Poder Executivo deixe de encaminhar a solicitação ao Poder Legislativo, tomando para si, por esta via, a decisão de não permitir a abertura de crédito adicional para o Poder Judiciário. Deve-se admitir a possibilidade do Governador acolher a demanda do Poder Judiciário, fazendo uso da liberdade que lhe é concedida pela margem de remanejamento, o que facilitaria o atendimento do pedido. Eventual discordância do Governador com a pretensão, no entanto, não pode ser tomada por ele, mas pelo Poder Legislativo, após receber a solicitação que lhe foi encaminhada, caso o Governador não a tenha atendido por meio do uso da margem de remanejamento. Assim, a interpretação que se deve dar ao texto do dispositivo legal importa em reconhecer ser obrigatório o encaminhamento ao Poder Legislativo da solicitação de abertura de crédito adicional efetuada pelo Poder Judiciário.

Essa autorização prévia para a abertura de créditos suplementares, à qual já se fez referência, é instrumento de flexibilidade na execução orçamentária, cujo uso deve ser moderado, sob pena de o Legislativo delegar ao Executivo poderes excessivos no gerenciamento das dotações orçamentárias, facultando-lhe promover alterações que venham a desnaturar o orçamento inicialmente aprovado. Essa atitude pode tornar o Poder Executivo soberano em matéria orçamentária, o que vilipendia as disposições constitucionais que outorgam ao Poder Legislativo competência para dispor sobre as leis orçamentárias $(\mathrm{CF}$, art. $48, \mathrm{II})$.

Liberalidade em demasia no uso dessa faculdade por parte do Poder Legislativo também provoca reflexos na autonomia financeira do Poder Judiciário. Isso porque, 
sendo necessários créditos suplementares e estando esses sob a gerência do Poder Executivo, tendo em vista a possibilidade ampla que lhe foi concedida de dispor sobre referidos créditos, o Poder Executivo ficará em uma condição privilegiada para obter recursos desta forma, em detrimento do Poder Judiciário, que terá de submeter seu pleito ao Poder Legislativo e, eventualmente, até mesmo ao próprio Poder Executivo.

Não se pode deixar de fazer referência ao mecanismo utilizado pelo Poder Legislativo do Estado de Minas Gerais. Há a previsão constitucional e legal de competência à Assembleia Legislativa para aprovar créditos suplementares ao seu próprio orçamento, observados limites fixados previamente. ${ }^{170}$

\title{
4.5.3. O art. 168 da CF e a entrega de recursos ao Poder Judiciário
}

Art. 168. Os recursos correspondentes às dotações orçamentárias, compreendidos os créditos suplementares e especiais, destinados aos órgãos dos Poderes Legislativo e Judiciário, do Ministério Público e da Defensoria Pública, serlhes-ão entregues até o dia 20 de cada mês, em duodécimos, na forma da lei complementar a que se refere o art. $165, \S 9^{\circ}$.

\begin{abstract}
Trata-se de dispositivo que vem reforçar a autonomia financeira do Poder Judiciário, ao fixar constitucionalmente uma data para a entrega dos recursos que lhe cabem por força das leis orçamentárias. Embora não tenha sido editada a lei complementar a que se refere o art. 165 , § $9^{\circ}$, da $C F$, e embora não haja referência expressa na Lei ${ }^{\circ} 4.320 / 64$, nem na LC 101/00 (LRF), o art. 168 é autoaplicável, de modo a assegurar o cumprimento de sua determinação independentemente da edição de legislação complementar. ${ }^{171}$
\end{abstract}

O art. 168 deixa claro ser atribuição do Poder Executivo conduzir o processo de execução orçamentária, mas o impede de um possível retardamento na entrega dos recursos aos demais poderes, o que seria um instrumento capaz de torná-lo onipotente, uma vez que tornaria os outros poderes dependentes dele, pelo controle que exerceria sobre a entrega dos recursos financeiros.

\footnotetext{
${ }^{170}$ No item 7.2.7 haverá referências mais detalhadas a respeito.

${ }^{171}$ Conforme já nos manifestamos anteriormente em Direito financeiro na Constituição de 1988, p. 106.
} 
O comando do art. 168 visa, pois, garantir a autonomia financeira do Poder

Judiciário, impedindo não somente que o Poder Executivo frustre a sua eficácia, como também evitando que os Estados-membros da Federação estabeleçam regras diferentes.

Nesse sentido, já se manifestou o STF em mais de uma oportunidade:

O comando emergente da norma inscrita no art. 168 da Constituição Federal tem por destinatário específico o Poder Executivo, que está juridicamente obrigado a entregar, em consequência desse encargo constitucional, até o dia 20 de cada mês, ao Legislativo, ao Judiciário e ao Ministério Público, os recursos orçamentários, inclusive aqueles correspondentes aos créditos adicionais, que foram afetados, mediante lei, a esses órgãos estatais. A prerrogativa deferida ao Legislativo, ao Judiciário e ao Ministério Público pela regra consubstanciada no art. 168 da Lei Fundamental da República objetiva assegurar-lhes, em grau necessário, o essencial coeficiente de autonomia institucional. A ratio subjacente a essa norma de garantia radicase no compromisso assumido pelo legislador constituinte de conferir às instituições destinatárias do favor constitutionis o efetivo exercício do poder de autogoverno que irrecusavelmente lhes compete. Assume inquestionável plausibilidade jurídica a tese, deduzida em sede de controle normativo abstrato, que sustenta a impossibilidade de o Estado-membro restringir a eficácia do preceito consubstanciado no art. 168 da Constituição Federal. Essa norma constitucional impõe a observância compulsória das unidades políticas da federação e não parece admitir - para efeito de liberação mensal das quotas duodecimais - qualquer discriminação quanto à natureza dos recursos orçamentários, sejam estes referentes, ou não, às despesas correntes de custeio. ${ }^{172}$

Ou ainda:

O preceito do art. 168 da Constituição da República, de eficácia imediata quanto à obrigação imposta ao Poder Executivo, assegura aos Poderes Legislativo e Judiciário, assim como ao Ministério Público, o repasse mensal, até o dia 20, dos recursos correspondentes a um doze avos das respectivas dotações orçamentárias globais. A finalidade desse preceito é óbvia: assegurar autonomia constitucional dos Poderes e da instituição referidos, no que respeita à gestão dos recursos que lhe são destinados no orçamento. Daí a "prioridade" na transferência das verbas. É inegável que o Poder Judiciário tem "direito" ao repasse tempestivo (até o dia 20 de cada mês) de um doze avos da dotação orçamentária global, não cabendo invocar normas legais anteriores à Carta de 1988, que frustrem a garantia. No plano concreto, não se poderão ignorar eventuais situações de total inexistência de recursos suficientes para cumprir na íntegra o dever constitucional, com intransponível e absoluta impossibilidade de obtê-los legalmente. Mas, nessas hipóteses, caberá ao Executivo provar cabalmente tais fatos, bem como que derivam de causas estranhas à conduta de seus próprios agentes, para se eximir da

${ }^{172}$ STF Pleno. ADIn 732/RJ, rel. Min. Celso de Mello, j. 22.5.1992, RTJ 143/57. 
responsabilidade. ${ }^{173}$

A norma do art. 168 da CF configura verdadeira "garantia de independência, que não está sujeita à programação financeira e ao fluxo da arrecadação"174, não sendo possível estabelecer datas diversas ${ }^{175}$, ocorrer atrasos ${ }^{176}$, haver parcelamentos ${ }^{177}$, ou qualquer outra medida que restrinja a eficácia do preceito constitucional. ${ }^{178}$

A falta do repasse desses recursos constitui, até mesmo, pressuposto ensejador da intervenção, nos termos dos arts. 34 , IV, e 36, I, da CF ${ }^{179}$, uma vez que a falta deles impede o Poder Judiciário de se desincumbir de suas funções constitucionais. ${ }^{180}$

\subsubsection{A execução financeira e o Poder Judiciário}

$\mathrm{O}$ art. $8^{\circ}$ da LRF estabelece que cabe ao Poder Executivo estabelecer a programação financeira e o cronograma de execução mensal de desembolso.

Esse procedimento, já mencionado, tem por objetivo compatibilizar com mais eficiência os ingressos de recursos com a realização das despesas, evitando, assim, que as oscilações nos fluxos financeiros em ambos os sentidos provoquem distorções que venham a prejudicar a execução do orçamento.

No entanto, ainda que de forma mitigada (já que tanto a programação financeira quanto o cronograma de desembolso deverão, ao final do exercício, cumprir as previsões da lei orçamentária), o controle sobre esses procedimentos confere ao responsável - no caso, o Poder Executivo - considerável parcela de poder sobre a realização dos gastos públicos.

\footnotetext{
${ }^{173}$ STF Pleno. MS 21.450-3/MT, j. 8.4.1992, rel. Min. Octávio Gallotti. RDA 189/306 e RTJ 140/818.

${ }^{174}$ STF Pleno. MS 21.450-3/MT, j. 8.4.1992, rel. Min. Octávio Gallotti, RDA 189/306 e RTJ 140/818, na ementa.

${ }^{175}$ STF. MS 21.273-0/SP, rel. Min. Néri da Silveira, j. 22.2.1996.

${ }^{176}$ STF Pleno. MS 23.267/SC, rel. Min. Gilmar Mendes, j. 3.4.2003, ementa.

${ }^{177}$ STF. MS 24.206-MC/AP, rel. Min. Maurício Corrêa, j. 18.3.2002.

${ }^{178}$ STF. ADIn 732/RJ, rel. Min. Celso de Mello, j. 22.5.1992, RTJ 143/57.

179 “Art. 34. A união não intervirá nos Estados nem no Distrito Federal, exceto para: [...] IV - garantir o livre exercício de qualquer dos Poderes nas unidades da Federação". "Art. 36. A decretação da intervenção dependerá: I - no caso do art. 34, IV, de solicitação do Poder Legislativo ou do Poder Executivo coacto ou impedido, ou de requisição do Supremo Tribunal Federal, se a coação for exercida contra o
} 
Em face da autonomia financeira prevista no art. 99 da CF, não se justifica consignar ao Poder Executivo a tarefa de estabelecer a programação financeira e o cronograma de execução mensal de desembolso para as despesas a cargo do Poder Judiciário. Novamente estar-se-á elevando aquele Poder a uma condição de superioridade em relação aos demais, pois a ele caberá fixar os valores que os outros poderes estarão autorizados a gastar mensalmente, sem que tenham qualquer possibilidade de interferir neste processo.

O art. 71 da LDO da união para 2005 atribui ao Poder Judiciário a tarefa de elaborar e publicar o cronograma anual de desembolso mensal. Esta medida, embora mais adequada em face da autonomia financeira do Poder Judiciário, ainda não é suficiente para se fazer respeitá-la, pois o Poder Executivo detém o controle da arrecadação, fluxo de receitas, bem como cálculo dos valores a serem entregues.

No caso do Poder Judiciário, mostra-se mais adequado e conforme à Constituição haver regra fixa, na Constituição ou por lei, que regule essa questão, a fim de que não fique a critério exclusivo do Poder Executivo decidir acerca desses valores, sob pena de serem descumpridos os preceitos constitucionais de separação e independência dos poderes, bem como da autonomia financeira do Poder Judiciário.

Isso deverá ser objeto de norma específica na lei complementar que vier a disciplinar os orçamentos públicos, nos termos do art. $165, \S 9^{\circ}$, da CF, como mencionado no art. 168 do referido diploma. Enquanto a questão não for definitivamente resolvida, cumpre criar mecanismos que permitam executar o orçamento sem ferir os princípios constitucionais que garantem a autonomia financeira do Poder Judiciário.

É o caso da Constituição do Estado de São Paulo, que em seu art. 171 estabelece:

O numerário correspondente às dotações orçamentárias do Poder Legislativo, do Poder Judiciário e do Ministério Público, compreendidos os créditos suplementares e especiais, sem vinculação a qualquer tipo de despesa, será entregue em duodécimos, até o dia 20 de cada mês, em cotas estabelecidas na programação financeira, com participação percentual nunca inferior à estabelecida pelo Poder Executivo para seus próprios órgãos.

Poder Judiciário."

${ }^{180}$ LEWANDOWSKI, Pressupostos materiais e formais da intervenção federal no Brasil, p. 95-6. 
Assim, são reduzidas as possibilidades do Poder Executivo interferir nos valores das cotas, impedindo-o de prejudicar o pleno exercício da autonomia financeira pelo Poder Judiciário.

É também o que ocorreu na esfera federal, ao se introduzir, na Constituição, pela EC 45/04, o sistema de duodécimos, que já vinha sendo utilizado por meio de disposições contidas nas leis de diretrizes orçamentárias. A nova redação do art. 168 da CF prevê:

\begin{abstract}
Art. 168. Os recursos correspondentes às dotações orçamentárias, compreendidos os créditos suplementares e especiais, destinados aos órgãos dos Poderes Legislativo e Judiciário, do Ministério Público e da Defensoria Pública, ser-lhes-ão entregues até o dia 20 de cada mês, em duodécimos, na forma da lei complementar a que se refere o art. $165, \S 9^{\circ} .{ }^{181}$
\end{abstract}

Com o sistema de duodécimos, fica assegurada a parcela de recursos que caberá ao Poder Judiciário, a cada mês, por meio de um mecanismo que se mostra mais compatível com a autonomia financeira do Poder Judiciário, assegurada pelo art. 99 da CF.

\title{
4.6. Fiscalização financeira e orçamentária e o Poder Judiciário
}

A questão do controle da Administração Pública é antiga, remontando ao próprio surgimento do Estado. ${ }^{182}$ Evidencia-se na própria Declaração dos Direitos do Homem e do Cidadão, da Assembleia Nacional francesa de 1789, a referência ao controle e à físcalização do poder público, consoante se verifica do art. 15: "A sociedade tem o direito de pedir a todo agente público contas de sua administração". Os sistemas de controle constituem-se em importante mecanismo de limitação dos poderes do Estado, colaborando no sistema de freios e contrapesos e evitando que ocorra o abuso do poder.

\footnotetext{
${ }^{181} \mathrm{O}$ trecho grifado foi introduzido pela EC 45/04.

182 "Em todos os tempos, desde os seus primórdios e incluindo as diversas etapas da sua evolução, o Estado sempre se preocupou em manter controle sobre as rendas públicas" (MILESKI, O controle da gestão pública, p. 174). "Os primeiros sistemas de controle dos atos de índole financeira da Administração Pública apareceram ainda na fase embrionária da organização do Estado" (CITADINI, O controle externo da administração pública, p. 11).
} 
Havendo um consenso de que deve existir controle sobre toda a Administração Pública $^{183}$, cumpre especificar qual seu conteúdo exato, a fim de que se possa compreender no que consiste e como é exercido.

Para Hely Lopes Meirelles, “controle, em tema de administração pública, é a faculdade de vigilância, orientação e correção que um Poder, órgão ou autoridade exerce sobre a conduta funcional de outro". ${ }^{184}$ Bento José Bugarin define controle como "a faculdade de vigilância, orientação e correção que um poder, órgão ou autoridade exerce sobre os atos praticados por outro, de forma a verificar-lhes a legalidade e o mérito e assegurar a consecução dos interesses coletivos". ${ }^{185}$

Há várias formas de se classificar o controle da Administração Pública, podendo ser utilizado o critério do Poder que o exerce (controles administrativo, legislativo e judiciário), o momento em que ocorre (controles prévio, concomitante e subsequente), o conteúdo e o objeto do controle (controles programático, administrativo e financeiro), bem como o órgão controlador - ou localização do órgão que o realiza (controles interno e externo), como explicamos em obra anterior. ${ }^{186}$

Podemos ainda fazer referência ao controle social da Administração Pública, composto pelas diversas formas de participação popular no exercício desta função, decorrentes do regime democrático. A Lei de Responsabilidade Fiscal trouxe grande incremento a esta forma de controle, tendo em vista os diversos mecanismos instituídos para dar transparência na gestão fiscal, previstos especialmente nos seus arts. 48 e 49.

Todas essas formas de classificação são úteis para melhor compreender o assunto. No entanto, far-se-á, a seguir, referência ao tema tendo por base a classificação acolhida pelo ordenamento jurídico nacional, expresso na Constituição Federal.

O Brasil utilizou, como se depreende da leitura da Constituição (arts. 70 e seguintes), a classificação que leva em consideração o órgão controlador.

Segundo essa classificação, o controle pode ser:

\footnotetext{
${ }^{183}$ Como anota com propriedade MEDAUAR (Controle da administração pública, p. 11).

${ }^{184}$ Direito administrativo brasileiro, p. 562.

${ }^{185}$ Controle das finanças públicas: uma visão geral, p. 12.

${ }^{186}$ Direito financeiro..., p. 7-8.
} 
a) interno, quando exercido no âmbito do próprio Poder;

b) externo, quando exercido pelo Poder Legislativo sobre toda a Administração Pública, abrangidos os três poderes.

Isso fica claro pela interpretação do texto constitucional, que trata do tema na Seção IX do Capítulo I do Título IV ("Da Fiscalização Contábil, Financeira e Orçamentária"), nos seguintes termos:

Art. 70. A fiscalização contábil, financeira, orçamentária, operacional e patrimonial da união e das entidades da administração direta e indireta, quanto à legalidade, legitimidade, economicidade, aplicação das subvenções e renúncia de receitas, será exercida pelo Congresso Nacional, mediante controle externo, e pelo sistema de controle interno de cada Poder.

\section{O controle interno está previsto no art. 74 da CF:}

Art. 74. Os Poderes Legislativo, Executivo e Judiciário manterão, de forma integrada, sistema de controle interno com a finalidade de:

I. - avaliar o cumprimento das metas previstas no plano plurianual, a execução dos programas de governo e dos orçamentos da união;

II. - comprovar a legalidade e avaliar os resultados, quanto à eficácia e eficiência, da gestão orçamentária, financeira e patrimonial nos órgãos e entidades da administração federal, bem como da aplicação de recursos públicos por entidades de direito privado;

III. - exercer o controle das operações de crédito, avais e garantias, bem como dos direitos e haveres da União;

IV. - apoiar o controle externo no exercício de sua missão institucional.

$\S 1^{\circ}$ - Os responsáveis pelo controle interno, ao tomarem conhecimento de qualquer irregularidade ou ilegalidade, dela darão ciência ao Tribunal de Contas da união, sob pena de responsabilidade solidária.

$\S 2^{\circ}$ - Qualquer cidadão, partido político, associação ou sindicato é parte legítima para, na forma da lei, denunciar irregularidades ou ilegalidades perante o Tribunal de Contas da União. 
A Lei 4.320/64 dispôs sobre o controle interno nos arts. 76 a 80, atribuindo ao Poder Executivo a tarefa de exercê-lo, tendo o art. 13 do Decreto-Lei $n^{\circ}$ 200/67 estatuído que o "controle das atividades da Administração Federal deverá exercer-se em todos os níveis e em todos os órgãos”.

Pelo sistema de controle interno, a Administração Pública realiza o controle sobre seus próprios atos, incluindo os órgãos que compõem a Administração direta (o chamado "controle cêntrico"), em que se inclui o Poder Judiciário, e a Administração indireta ("controle excêntrico").

A Constituição de 1988 inovou ao estabelecer que cada um dos poderes deverá manter, de forma integrada, sistema de controle interno, haja vista que, até então, esse controle era organizado apenas na esfera do Poder Executivo. Em razão disso, verificase não estar ainda completamente implantado em todos os poderes, nas três esferas de Governo.

Assim, toda a Administração Pública, incluído os três poderes, deve manter órgãos destinados a realizar este tipo de controle e fiscalização, de modo a aferir a legalidade, legitimidade e economicidade de seus atos, nos termos dos arts. 70 e 74 da CF. ${ }^{187}$

É interessante deixar registrada a experiência gaúcha, que estabelece um sistema de controle interno único para todos os poderes, previsto na própria Constituição Estadual. ${ }^{188}$ Tem como órgão responsável a Contadoria e Auditoria-Geral do Estado, órgão do Poder Executivo estadual, que exerce o controle sobre os três poderes do Estado.

Embora esse sistema aparentemente não se ajuste ao previsto na Constituição Federal, pois o art. 74 estabelece que cada um dos poderes deverá manter sistema de controle interno, informa-nos Hélio Mileski que:

Não tem havido contestação a esse critério constitucional adotado no Rio Grande do Sul, na medida em que o controle interno está estruturado sistemicamente, com a Contadoria e Auditoria-Geral do Estado mantendo

\footnotetext{
${ }^{187}$ CONTI, Direito financeiro..., p. 55.

188 “Art. 76. O sistema de controle interno previsto no art. 74 da Constituição Federal terá, no Estado, organização una e integrada, compondo órgão de contabilidade e auditoria-geral do Estado, com delegações junto às unidades administrativas dos três Poderes, tendo sua competência e quadro de pessoal definidos em lei."
} 
delegações nos três Poderes do Estado, chamadas de contadorias seccionais, e a execução das suas atividades controladoras está sendo efetuada de maneira satisfatória, promovendo a comprovação da legalidade e a avaliação dos resultados da ação realizada pelos gestores públicos, mas sem agredir a autonomia e a independência dos Poderes, uma vez que esse controle atua somente nos aspectos contábeis, financeiros, orçamentários, operacionais e patrimoniais, sem causar interferência nas funções constitucionais destinadas a cada Poder. ${ }^{189}$

O controle externo no Brasil é exercido pelo Poder Legislativo ${ }^{190}$ sobre todos os demais Poderes e órgãos da Administração Pública, compreendendo toda e qualquer pessoa ou entidade que utilize, arrecade, guarde, gerencie ou administre dinheiro, bens e valores públicos.

Esse controle, que abrange essencialmente a fiscalização das contas e dos bens públicos, realiza-se por meio de um órgão auxiliar, que pode ser ou não organizado na forma de um colegiado.

Com relação ao modelo de controle externo da Administração Pública, a doutrina reconhece existirem dois grandes sistemas, conforme o tipo de órgão adotado para auxiliar o Poder Legislativo.

O primeiro é o chamado modelo "inglês" ou "anglo-saxônico"191, em que a fiscalização é exercida por um órgão não colegiado, do tipo Controladoria ou Auditoriageral. É o que ocorre nos Estados Unidos com o General Accounting Office (GAO); no Reino Unido, com o National Audit Office; na Austrália, o Australian National Audit Office; e no Canadá, o Office of the Auditor General of Canada - entre outros.

Outro sistema é o modelo "francês"192 ou "continental europeu"193, em que o órgão auxiliar do Poder Legislativo é do tipo Tribunal de Contas, órgão colegiado integrado por Ministros ou Conselheiros.

Este último sistema é o adotado no Brasil, consoante se depreende do art. 71 da $\mathrm{CF}$, ao prever, na esfera federal, que o controle externo será exercido com o auxílio do

\footnotetext{
${ }^{189}$ O controle..., p. 169-70.

${ }^{190}$ Há países que adotam outro sistema, criando um órgão independente para exercer o controle externo; outros o incluem no âmbito do Poder Judiciário.

${ }^{191}$ LAUBÉ, Sistemas..., p. 171.

${ }^{192}$ Idem.
} 
Tribunal de Contas da união (TCU). O primeiro Tribunal de Contas do Brasil surgiu em 1890 (Decreto 966-A, de 1890), tendo sido instalado em 1893. A Constituição de 1891 previu o Tribunal de Contas no art. 89. ${ }^{194}$

Outros países também seguem o mesmo modelo, como é o caso da França, onde a Cour des Comptes exerce essa função, e do Uruguai, onde existe o Tribunal de Cuentas.

Nos países que adotam o modelo federativo de Estado, como o Brasil, pode haver diferentes formas de organização do sistema de controle externo, tendo em vista a multiplicidade de esferas de governo e de poderes legislativos.

$\mathrm{Na}$ esfera federal, o controle externo no Brasil é exercido pelo Congresso Nacional, com o auxílio do Tribunal de Contas da união.

$\mathrm{Na}$ esfera estadual, as Assembleias Legislativas exercem o controle externo, com o auxílio dos Tribunais de Contas dos Estados.

No âmbito dos municípios, há variações, conforme o Estado da Federação. Alguns Estados têm um único Tribunal de Contas Estadual, que auxilia a Assembleia Legislativa no controle das contas estaduais e as Câmaras Municipais no controle das contas dos municípios. Outros têm dois Tribunais de Contas Estaduais: um denominado Tribunal de Contas do Estado, que auxilia a Assembleia Legislativa no controle das contas da Administração Pública estadual; outro, usualmente denominado Tribunal de Contas dos Municípios, ou Conselho de Contas dos Municípios, presta auxílio às Câmaras Municipais no controle externo das finanças dos municípios.

Há, ainda, dois Tribunais de Contas Municipais, sendo um na cidade de São Paulo e outro na cidade do Rio de Janeiro, os quais auxiliam as respectivas Câmaras Municipais na fiscalização das contas públicas desses municípios. Não há possibilidade

\footnotetext{
${ }^{193}$ FRANCO, Finanças..., p. 458.

194 "Art. 89. É instituído um Tribunal de Contas para liquidar as contas da receita e despesa e verificar a sua legalidade, antes de serem prestadas ao Congresso."
} 
de serem criados outros Tribunais de Contas no âmbito municipal, em face da vedação expressa contida no art. $31, \S 4^{\circ}$, da CF. ${ }^{195}$

Far-se-á a seguir um sucinto panorama do sistema de controle das contas públicas vigente no Brasil, voltado para os pontos de interesse do Poder Judiciário.

\subsubsection{O controle interno do Poder Judiciário}

O controle interno do Poder Judiciário, na esfera federal, tem sido realizado de maneira difusa, havendo órgãos de controle interno em cada um dos Tribunais Superiores.

No Supremo Tribunal Federal, o controle interno está a cargo da Secretaria de Controle Interno, instituída pelo Ato Regulamentar 32/01 e prevista atualmente no Regulamento da Secretaria do STF, arts. 60 a $62 .{ }^{196}$ É subordinada ao Presidente do Tribunal e tem por finalidade

\footnotetext{
“acompanhar a gestão de pessoal, orçamentária, financeira e patrimonial do Tribunal, bem como a execução dos programas de trabalho; orientar a atuação dos gestores; verificar a utilização regular e racional dos recursos e bens públicos e avaliar os resultados obtidos pela Administração" (art. 60).
}

É dividida em duas Coordenadorias: a Coordenadoria de Acompanhamento, Avaliação e Orientação (CAOR) e a Coordenadoria de Auditoria (CAUD).

Sistemas equivalentes têm sido adotados em outros Tribunais Federais, como se pode constatar de alguns exemplos a seguir.

O Superior Tribunal de Justiça criou a Secretaria de Controle Interno por meio da Resolução 1, de 1998, como órgão especializado na administração financeira, contabilidade e auditoria, estando subordinada à Presidência do Tribunal. ${ }^{197}$

No âmbito da Justiça Federal, as atividades de controle interno estão centralizadas no Conselho da Justiça Federal, órgão que exerce sua supervisão

\footnotetext{
195 "É vedada a criação de Tribunais, Conselhos ou órgãos de Contas Municipais."

196 Texto consolidado. Disponível em: www.stf.gov.br. Acesso em 19.1.2005.

${ }^{197}$ MILESKI, O controle..., p. 166.
} 
administrativa e orçamentária e funciona junto ao STJ (CF, art. 105, parágrafo único; Lei ${ }^{\circ} 8.472 / 92$, art. $2^{\circ}$ ).

A Secretaria de Controle Interno do Tribunal Superior Eleitoral está prevista no art. $8^{\circ}$-A da Seção VI-A do Regulamento Interno da Secretaria do Tribunal, cabendo-lhe planejar, coordenar e supervisionar as atividades de controle interno da Corte, além de propor diretrizes, normas, critérios e programas a serem adotados na execução dessas atividades. $^{198}$

$\mathrm{Na}$ esfera estadual, dada a autonomia administrativa de que goza o Poder Judiciário, há várias formas de organização do controle interno. Em alguns Estados, o Poder Judiciário dispõe de controle em cada um dos Tribunais que o compõem, e em outros, há um sistema de controle interno único.

\subsubsection{O controle externo do Poder Judiciário}

O sistema adotado pela Constituição brasileira prevê que a fiscalização contábil, financeira, orçamentária operacional e patrimonial do Poder Judiciário far-se-á pelo Poder Legislativo, mediante controle externo, com o auxílio do Tribunal de Contas competente.

Essa situação decorre das disposições constitucionais em vigor, oriundas de poder constituinte originário, que atribuem ao Poder Legislativo supremacia em matéria orçamentária, à semelhança do que ocorre em outros países. Ao Poder Legislativo compete dispor sobre as leis orçamentárias e outros assuntos de natureza financeira (CF, arts. 48, II, e 49, IX e X, principalmente), bem como exercer a físcalização das contas e do patrimônio públicos (art. 70).

As contas do Poder Judiciário devem, dessa forma, sujeitar-se ao sistema de controle externo, que as aprecia e julga, com os atos de fiscalização sendo realizados pelo Tribunal de Contas respectivo.

\footnotetext{
198 Regulamento Interno da Secretaria do Tribunal Superior Eleitoral. 2. ed. 2003. Disponível em: www.tse.gov.br. Acesso em: 19.1.2005.
} 
Ao Poder Legislativo compete julgar anualmente as contas prestadas pelo chefe do Executivo (CF, art. 49, IX), que as apresenta em sua forma global, ou seja, abrangendo toda a Administração Pública, incluídos os três Poderes. Assim, na esfera federal, o Presidente da República, consolidando todas as contas da Administração Pública federal, elabora o balanço geral das contas do exercício financeiro findo e o remete ao Tribunal de Contas da união, que emitirá parecer prévio ${ }^{199}$, para, em seguida, encaminhar as contas apresentadas ao Congresso Nacional (CF, arts. 71, I, e 84, XXIV). Do exposto, infere-se que as contas do Poder Judiciário são submetidas ao Poder Legislativo enquanto parte das contas gerais do Estado, apresentadas pelo chefe do Poder Executivo, que as terá julgadas. Não há, pois, um julgamento específico das contas do Poder Judiciário, enquanto tal, pelo Poder Legislativo, analisando-se sob o aspecto ora considerado. O que existe, neste caso, é um julgamento das contas do Estado, que, nesta situação, é representado pelo chefe do Poder Executivo, o qual tem a incumbência de prestar as contas, na forma da Constituição, como dispõem os artigos constitucionais citados.

No entanto, cabe ressaltar que compete ao Tribunal de Contas da União ${ }^{200}$, além de outras atribuições, "julgar as contas dos administradores e demais responsáveis por dinheiros, bens e valores públicos da administração direta e indireta" (art. 70, II), bem como "aplicar aos responsáveis, em caso de ilegalidade de despesa ou irregularidade de contas, as sanções previstas em lei, que estabelecerá, entre outras cominações, multa proporcional ao dano causado ao erário" (art. 71, VIII).

Os Presidentes dos Tribunais, além de outras pessoas envolvidas na administração do Poder Judiciário (órgão da Administração direta), pertencentes ou não à Magistratura, administram dinheiros, bens e valores públicos, razão pela qual estão sujeitos ao julgamento de suas contas pelos Tribunais de Contas e suscetíveis às punições aplicáveis pela referida instituição, entre as quais está a multa.

Nesse ponto, é relevante ressaltar que os Tribunais de Contas, embora atuem como órgãos auxiliares do Poder Legislativo, não têm com ele qualquer vínculo de

\footnotetext{
${ }^{199}$ As contas do Poder Judiciário recebem parecer prévio separadamente, nos termos do art. 56 da LRF.

${ }^{200}$ Faz-se a abordagem, neste ponto, com relação à esfera federal do governo. Ressalte- se que as Constituições Estaduais costumam reproduzir os dispositivos citados, havendo muita semelhança no que se
} 
subordinação, consoante entendimento da doutrina predominante. Como já expusemos em obra anterior:

\begin{abstract}
Não obstante estas respeitáveis opiniões, parece mais adequada a posição, adotada pela maior parte da doutrina, de que o Tribunal de Contas é órgão independente e autônomo, cujas funções lhe são atribuídas diretamente pela Constituição, e atua como auxiliar do Poder Legislativo no exercício do controle externo, sem que isto importe em qualquer vínculo de hierarquia ou subordinação. Neste sentido já se manifestou o próprio Supremo Tribunal Federal: "o Tribunal não é preposto no Legislativo. A função, que exerce, recebe-a diretamente da Constituição, que lhe define as atribuições" (Representação 1.179/ES, STF Pleno, j. 29.6.1984, RDA 158/196). ${ }^{201}$
\end{abstract}

Não há, pois, que se falar, nesse caso, em subordinação do Poder Judiciário, ou de seus integrantes, ao Poder Legislativo, no que se refere ao julgamento das contas dos administradores públicos.

\title{
4.6.3. O “controle externo” do Poder Judiciário pelo Conselho Nacional de Justiça
}

Nos itens anteriores fez-se uma exposição a respeito do controle da Administração Pública brasileira, explicitando-se, por meio da classificação que considera o órgão que o exerce, se é "interno" ou "externo" ao Poder, a qual inclui os sistemas de controle interno e externo. O controle externo caracteriza-se, como visto, por ser realizado pelo Poder Legislativo sobre toda a Administração Pública, abrangendo os três Poderes.

Já há alguns anos vem sendo objeto de referências na mídia, no Congresso, na Magistratura e na sociedade brasileira em geral a instituição de um "controle externo" sobre o Poder Judiciário.

É evidente que a expressão não se ajusta ao exposto, devendo ser considerada não no aspecto técnico - com o significado que o Direito Financeiro lhe confere -, mas sob uma ótica mais ampla. Trata-se de um órgão de controle, não apenas administrativo e orçamentário, mas incluindo aspectos funcionais, que tem em sua composição membros estranhos ao Poder Judiciário. Tem-se, assim, um órgão que, contendo 
pessoas não pertencentes aos quadros da Magistratura, e com atribuições de controle sobre atos de interesse do Poder Judiciário, acaba exercendo o alegado "controle externo" deste Poder.

A EC 45, de 8.12.2004, publicada em 31.12.2004, destinada a promover a "reforma do Judiciário", trouxe, como uma das alterações, a criação do Conselho Nacional de Justiça, por meio da inserção do inciso I-A no art. 92 da CF, que passou a ter a seguinte redação:

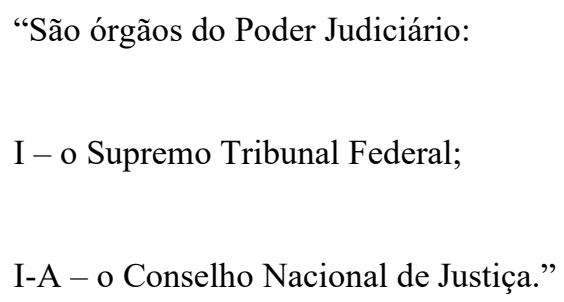

Sua composição está prevista no art. 103-b. São quinze membros, sendo: um Ministro do STF, um Ministro do STJ, um Ministro do TST, um Desembargador de Tribunal de Justiça, um Juiz Estadual, um Juiz de TRF, um Juiz Federal, um Juiz de TRT, um Juiz do Trabalho, um membro do MPU, um membro do Ministério Público estadual, dois advogados e dois cidadãos. ${ }^{202}$ Os membros são nomeados pelo Presidente da República, depois de aprovada a escolha pela maioria absoluta do Senado Federal.

Criou-se, por meio dessas disposições constitucionais, o discutido "órgão de controle externo" do Poder Judiciário. ${ }^{203}$

Ver-se-á, pelos argumentos a seguir, não se mostrar conforme à Constituição, nem adequada e conveniente à forma de organização do Estado brasileiro, a instituição de órgão dessa natureza, com essa forma de composição.

No que se refere ao aspecto financeiro, compete ao Conselho o controle da atuação administrativa e financeira do Poder Judiciário (art. 103-B, $\S 4^{\circ}$, caput).

\footnotetext{
${ }^{202}$ Dos dois cidadãos exige-se notável saber jurídico e reputação ilibada, e serão indicados um pela Câmara dos Deputados e outro pelo Senado Federal.

${ }^{203}$ Que, na verdade, não pode ser considerado "externo", mas interno, uma vez que passou a integrar o Poder Judiciário, conforme se constata da leitura do art. 92, caput, e inciso I-A, que o instituiu, já transcrito.
} 
$\mathrm{O}$ art. 74 da CF exige que cada um dos poderes mantenha, de forma integrada, sistema de controle interno, com a finalidade, especialmente no que toca ao Poder Judiciário, de executar os programas de governo e seu orçamento, comprovar a legalidade e avaliar os resultados, quanto à eficácia e à eficiência, da gestão orçamentária, financeira e patrimonial de seus órgãos, bem como apoiar o controle externo no exercício de sua missão institucional.

Assim, é razoável e até recomendável a criação de um órgão que possa exercer esse controle interno de forma unificada, em cada esfera de Governo (federal e estaduais, no caso do Poder Judiciário), o que facilitaria a integração com os outros órgãos, na forma determinada pelo texto constitucional. No entanto, essas atribuições não estão abrangidas pela competência do Conselho Nacional de Justiça, consoante se depreende do Regimento Interno vigente ${ }^{204}$.

Compete-lhe, todavia, a tarefa de emitir parecer sobre a proposta orçamentária elaborada pelo Poder Judiciário a ser encaminhada ao órgão central do Sistema de Planejamento e de Orçamento Federal, para fins de consolidação do projeto de lei orçamentária $^{205}$. Cabe-lhe ainda emitir parecer nos projetos de lei relativos aos pedidos de créditos adicionais (LDO da união para 2006, art. 63, § 16), bem como nos projetos de lei de iniciativa do Poder Judiciário que versarem sobre transformação de cargos, aumento de gastos com pessoal e encargos sociais (LDO da União para 2006, art. 88, IV).

A instituição de órgão de controle do Poder Judiciário, composto por membros estranhos à Magistratura, no entanto, mostra-se em desacordo com os princípios constitucionais da separação dos poderes e da independência do Poder Judiciário, insculpidos no art. $2^{\circ}$ da CF.

Tal se deve principalmente por ferir aspectos voltados à autonomia funcional da Magistratura, tendo em vista a influência que pode vir a exercer, ainda que indiretamente, sobre o poder decisório dos juízes. Pode atingir também aspectos da

\footnotetext{
${ }^{204}$ Disponível em www.cnj.gov.br. Acesso em: 20 abr. 2006.

${ }^{205}$ LDO da União para 2006 (Lei n. 11.178/05), art. 14, § único.
} 
autonomia institucional do Poder Judiciário, razão pela qual se justifica a abordagem do tema.

A independência do Poder Judiciário é reconhecidamente imprescindível para garantir a existência do Estado Democrático de Direito, configurando verdadeiro pilar no qual se sustenta; essa independência manifesta-se por meio da autonomia institucional assegurada ao Poder Judiciário, bem como pela autonomia funcional concedida à Magistratura. ${ }^{206}$

Entre as competências do Conselho Nacional de Justiça está avocar processos disciplinares e determinar a remoção, a disponibilidade e até mesmo a aposentadoria compulsória de magistrados, além de outras sanções, podendo rever de ofício os processos disciplinares de juízes e membros de Tribunais julgados há menos de um ano (art. 103-B, $\left.\S 4^{\circ}, \mathrm{V}\right)$.

Conceder tais poderes a órgão em cuja composição há integrantes estranhos aos quadros da Magistratura, que não tenham exercido o cargo de Magistrado e tomado conhecimento das atividades realizadas cotidianamente, poderá resultar em julgamentos injustos, o que certamente é temerário, e poderá levar insegurança aos Juízes no exercício de suas atividades jurisdicionais e mesmo administrativas, enfraquecendo sua independência funcional.

São várias as manifestações que reconhecem a inconstitucionalidade da criação de órgão com finalidade de exercer "controle externo" do Poder Judiciário em cuja composição inserem-se membros que dele não fazem parte.

O Ministro do STF José Néri da Silveira, em aula magna proferida aos alunos da Faculdade de Direito da universidade Federal do Rio Grande do Sul, à qual já se fez referência, expõe com clareza e firmeza esta posição:

Compreendo, na linha dessas sucintas observações, destarte, que não cabe, em reforma constitucional, em que presentes as limitações materiais do art. $60, \S 4^{\circ}$, da Constituição, a criação, em nossa ordem jurídica, de órgão de controle do Poder Judiciário, ou criado no âmbito de qualquer dos outros Poderes, ou integrado por autoridades desses Poderes, ou de qualquer deles,

\footnotetext{
${ }^{206}$ Sobre este assunto, ver item 3.4.
} 
ou ainda, com representantes de instituição não pertencente ao Poder Judiciário, ou de membros integrados, nesse órgão, sem a participação do Judiciário. Afetada ficará, em qualquer dessas hipóteses, a independência do Poder Judiciário e, assim, violada a cláusula pétrea da separação dos Poderes, ut art. $60, \S 4^{\circ}$, III, da Lei Maior. Com esta compatível é, entretanto, a existência de órgão de controle dos atos do Judiciário, inclusive de natureza disciplinar, quer no plano da união, quer no dos Estados, ou de âmbito nacional, desde que integrado no Poder e composto exclusivamente por magistrados, ou, ao lado destes, por não magistrados, desde que investidos, nas funções, pelo Poder Judiciário. Somente assim o funcionamento do Poder Judiciário poderá ficar imune a influências dos outros Poderes, com evidente prejuízo à boa prestação jurisdicional, que repugna quaisquer formas de coação ou ameaça aos juízes ou tribunais, expressas ou larvadas, eis que acabam por afetar, imediata e diretamente, a independência do Judiciário, nas várias dimensões aludidas e, assim, por igual, concorrem à descaracterização da fisionomia de nosso sistema político, que possui, no primado da Constituição e na independência do Judiciário, conotações essenciais. ${ }^{207}$

\section{Alexandre de Moraes tem a mesma posição e evidencia a incompatibilidade desse órgão com o princípio da separação de poderes e com o Estado Democrático de Direito:}

Não se consegue conceituar um verdadeiro Estado de Direito Democrático sem a existência de um Poder Judiciário autônomo e independente para que exerça sua função de guardião das leis [...].

A harmonia prevista entre os Poderes de Estado vem acompanhada de um detalhado sistema de freios e contrapesos (check and balances), consistente em controles recíprocos.

Assim, é necessário lembrar, dentro dessa ideia de reciprocidade de controles, que a fiscalização contábil, financeira, orçamentária, operacional e patrimonial das unidades administrativas do Poder Judiciário deverá ser realizada pelo Poder Legislativo, por meio do próprio Congresso Nacional, com o auxílio do Tribunal de Contas da União, no âmbito nacional. [...]

A criação de um órgão autônomo e externo ao Poder Judiciário, com a missão de fiscalizá-lo e controlá-lo, acabaria por desrespeitar flagrantemente os arts. $2^{\circ}$ e $60, \S 4^{\circ}$, III, da Constituição Federal, configurando-se em uma intervenção dos demais poderes na magistratura, que ficaria submetida hierárquica e politicamente a um órgão político, composto por integrantes pertencentes aos demais Poderes ou instituições estatais, e, em consequência, haveria o grave risco de comprometimento da imparcialidade dos magistrados. 208

\footnotetext{
${ }^{207}$ Dimensões..., p. 186-7.

${ }^{208}$ Controle..., p. 60-2.
} 
O prejuízo causado por um órgão dessa natureza à independência funcional da Magistratura é ressaltado por Sérgio Pinto Martins, ao asseverar:

\begin{abstract}
Controlar o Judiciário externamente é, portanto, acabar com a independência dos juízes de livremente julgar, de acordo com o seu livre convencimento motivado, mas sempre subordinado à lei. A independência do juiz é uma garantia da sociedade de ter um magistrado íntegro e imparcial para dirimir as questões que lhe são submetidas à apreciação, sem qualquer tipo de pressão sobre seu trabalho ou qualquer outra interferência externa, distribuindo justiça. A independência e a isenção do juiz são, por conseguinte, condições imprescindíveis conferidas ao julgador para que bem possa desempenhar o seu mister, juntamente com a vitaliciedade, inamovibilidade, irredutibilidade de subsídios e aposentadoria integral com base na remuneração dos ativos. ${ }^{209}$
\end{abstract}

Vê-se que a questão já foi objeto de inúmeras manifestações na doutrina. Foi também submetida à apreciação do Supremo Tribunal Federal, que proferiu decisões definitivas, cujos trechos vale transcrever.

O Ministro Octavio Gallotti, em seu voto em uma ADIn, mostra a incompatibilidade da criação de órgão semelhante pela Constituição do Estado da Paraíba:

Não é por outra razão, senão para assegurar-lhes eficaz independência - e jamais sob a acanhada inspiração de algum postulado de eficiência ou descentralização, porventura haurido da técnica ou ciência da Administração -, que o regime político dos povos cultos tem consagrado o autogoverno dos Tribunais e sua autonomia administrativa, financeira e orçamentária (artigos 96, 99 e parágrafo, e 168 da Constituição da República).

Do exercício dos poderes de fiscalização da atividade administrativa e do desempenho dos deveres funcionais do Poder Judiciário estadual, outorgados, sem reserva, pela Constituição da Paraíba, afigura-se indissociável (até mesmo sob pena de se revelarem eles ociosos) alguma parcela de ingerência e de iminência repressiva do Colegiado estranho ao Judiciário, que se pretende incumbir dessas tarefas, em detrimento da integridade da garantia de independência da magistratura.

Não é à toa que, sempre que vozes se avolumam na pregação deste ou daquele tipo de controle externo aos Tribunais, coincide a direção desse rumor com a frustração do interesse (até, às vezes, respeitável) de algum grupo, ou pessoa, mais dominada pela paixão contrariada, seja ela cívica, política, corporativa, ou simplesmente individual.

${ }^{209}$ Controle externo..., p. 18. 
Mostram, todavia, a ciência do Direito Constitucional e a observação histórica dos costumes políticos que a independência de um Poder é inseparável da autonomia administrativa e da segurança proporcionada pela conquista da gestão autônoma dos meios postos pelo Estado à sua disposição, para garantir a administração e a distribuição de Justiça, papel destinado pela Constituição à responsabilidade de um Poder Judiciário nacional. Não à de outros órgãos e entidades, que a ele não pertençam, como se estabelece no dispositivo impugnado (ADIn 135/Pb. STF Pleno. Rel. Min. Octávio Gallotti, j. 21.11.1996).

A ementa da ADIn 98-5/MT mostra com clareza e precisão os argumentos que evidenciam a inconstitucionalidade de instituição de órgão de controle externo:

É inconstitucional a norma estadual que cria órgão de "controle externo" do Poder Judiciário, com participação de agentes ou representantes dos outros Poderes do Estado, eis que tal dispositivo afronta o princípio da separação dos Poderes, o qual constitui um dos traços característicos do Estado Democrático de Direito, de que são corolários o autogoverno dos Tribunais e a sua autonomia administrativa, financeira e orçamentária (ADIn 98-5/MT. Sessão plenária, j. 7.8.1997, rel. Min. Sepúlveda Pertence, DJU 31.10.1997, RT 749/181).

Nesta ação, cabe destacar trecho do voto do Ministro Sepúlveda Pertence, relator do processo:

$\mathrm{Na}$ Europa, como visto, os conselhos superiores da magistratura representaram um avanço significativo no sentido da independência do Judiciário, na medida em que nada lhe tomaram do poder de administrar-se, de que nunca dispuseram, mas, ao contrário, transferiram a colegiados onde a magistratura tem presença relevante, quando não majoritária, poderes e governo judicial que historicamente eram reservados ao Executivo.

Ao contrário, a mesma instituição traduziria retrocesso e violência constitucional, onde, como sucede no Brasil, a ideia da independência do Judiciário está extensamente imbricada com os predicados do autogoverno crescentemente outorgados aos Tribunais.

Na mesma linha de raciocínio, há um último ponto a sublinhar: em todos os países que têm instituído os conselhos de formação heterogênea para o governo do Judiciário - com a única exceção, que passou a adotar o princípio da unidade jurisdicional (Const. de 1978, art. 117, 5) - à magistratura judicial - por motivos históricos similares aos já recordados -, jamais se entregou nem o controle da legalidade da administração, nem muito menos o de constitucionalidade das leis.

Quanto aos órgãos da jurisdição constitucional, é significativo notar que mesmo onde - como sucede na Espanha (Tomas y Valiente ...) e em Portugal 
(Canotilho e vital Moreira, ...) - o Tribunal Constitucional exerce jurisdição e se reputa integrante do Poder Judiciário, é dele próprio o seu governo e a ninguém ocorreria submeter os seus juízes ao poder disciplinar dos Conselhos Superiores.

No sistema brasileiro, todo órgão judiciário é juiz da legalidade da administração e constitucionalidade das leis.

É um dado a mais para evidenciar o trauma que representaria ao modelo positivo brasileiro de independência do Judiciário, que tem um de seus pilares no autogoverno, a introdução em um Estado-membro de um órgão de administração e disciplina em cuja heterogênea formação se abrissem flancos à intromissão dos outros Poderes.

Note-se que no caso vertente, de Mato Grosso, essa intromissão é muito mais funda que no da Paraíba, objeto da decisão precedente: neste - afora o Presidente da $\mathrm{OAB}$, a cuja presença a definição constitucional da advocacia como função essencial à Justiça dá conotação especial -, o Executivo só estaria representado pelo Procurador Geral do Estado e o Legislativo, por um representante da Assembleia Legislativa: na Constituição do Mato Grosso além de dois Desembargadores e um Juiz e afora o Presidente da seção da OAB e um outro advogado, do chefe do Ministério Público e um outro Promotor, do da Defensoria Pública e um outro Defensor -, o Legislativo teria o vice-Presidente da Assembleia e o Executivo, o vice-Governador, o Procurador Geral do Estado e outro Procurador, e o Secretário de Justiça (note-se que, na Europa, só o Garde dês Sceaux francês é membro do Conselho); para completar tudo isso, um serventuário da Justiça.

Parecendo ter a intenção de sepultar a tese que via possibilidade de instituição de órgão de "controle externo" do Poder Judiciário com integrantes estranhos à Magistratura, uniformizaram-se as decisões anteriormente referidas na Súmula 649, cuja íntegra é a seguinte:

É inconstitucional a criação, por Constituição estadual, de órgão de controle administrativo do Poder Judiciário do qual participem representantes de outros Poderes ou entidades.

No entanto, ao apreciar a ADIn 3.367-1/DF, movida pela Associação dos Magistrados brasileiros (AMB) e protocolada em 9.12.2004, que pleiteou o reconhecimento da inconstitucionalidade da criação do Conselho Nacional de Justiça nos termos previstos pela EC 45/04, o mesmo STF, em decisão tomada em 13.4.2005, julgou-a improcedente, por maioria de votos, reconhecendo constitucional o Conselho Nacional de Justiça. 
Do exposto, constata-se, indiscutivelmente, ser questão polêmica, uma vez que há argumentos que justificaram a decisão tomada pela nossa Egrégia Corte Suprema, ao reconhecer a inconstitucionalidade da criação de órgão de "controle externo" do Poder Judiciário, que se relacionam justamente ao fato de ferir a independência e autonomia deste Poder.

Posteriormente, a mesma Corte, com outra composição, uma vez que houve a alteração de vários Ministros no período, não reconhece a prevalência destes mesmos argumentos e decide em sentido oposto.

Não obstante a mudança de posição ocorrida no STF, os argumentos expostos, que reconheceram a incompatibilidade da criação de órgão de "controle externo" do Poder Judiciário, continuam válidos e mostram a inconstitucionalidade da instituição do mencionado órgão, por afronta ao princípio da separação de poderes, contrariando o disposto no art. $60, \S 4^{\circ}$, III, da CF. 